\title{
Indonesian Muslims and cultural networks
}

\author{
Hairus Salim HS
}

Situated in the midst of the turmoil of an Afro-Asian political movement that began in 1940, reached its high point in the Asia Africa Conference of Bandung in 1955, then descended to failure at the 'Second Bandung' in Algiers in 1965, Indonesia - along with Egypt and India - according to David Kimche (1973), occupied a position of non-alignment, that is, neutrality in a political and ideological sense with respect to the Cold War between the communist and capitalist blocs. What is especially true for Indonesia, writes Kimche, is that this neutrality was intensified by an attitude of 'militant anti-colonialism'. In fact, non-aligned countries formed a minority of the African-Asian nations, but African-Asian politics was exactly what the anti-colonial and anti-imperialist group was calling for.

The resulting tendency, as formulated by Soekarno and shaped by a combination of factors (anti-Western indoctrination absorbed from Japan during World War II; four years of a war of independence against Western nations; Allied support for the Netherlands), led to an intensely anti-Western attitude in Indonesia and a simultaneous drift toward the Communist Bloc. It was this position that characterized Indonesia's orientation to the outside world and spread to various areas of life during the era of the Soekarno government until its fall.

Any kind of relationship with Communist Bloc countries was interpreted in an extremely positive sense, because this mirrored a nationalist, anti-colonial and anti-imperialist attitude. And the state supported such relations in many areas. On the other hand, any kind of contact with the West, including consumption of or imitation of a taste for products of Western culture, was considered to be 'anti-revolutionary' and as supporting an imperialist and colonial perspective.

In a political context such as this, it is interesting that cultural ties between Indonesia and Islamic countries were continuously cul- 
tivated; in many respects they could be said to have strengthened. Thus, beneath all the sound and fury generated by the communist and capitalist blocs that served to decorate the cultural debates of this period, cultural relations with Islamic nations like Egypt and Pakistan persisted.

In this essay I want to trace the human networks and communication pathways that made up these cultural relations by examining the roles of three artists and cultural leaders: Haji Abdul Malik Karim Amrullah (Hamka) (1908-1981), Usmar Ismail (1921-1971), and Bahrum Rangkuti (1919-1977). By limiting the approach to an examination of the roles of just these three important figures, it is very possible that I am ignoring others who played similar roles. And by stressing only the connections and networks involving these three leaders with Islamic nations, I am admittedly ignoring their relations with other (non-Islamic) countries.

In 1950, Hamka served in the Department of Religion as a Member of the Council for Indonesian Pilgrims to Mecca (Anggota Majelis Perjalanan Haji Indonesia). Hamka took advantage of this opportunity to travel to countries in the Middle East. Making trips to other Arab countries while providing support to or solving the problems encountered by pilgrims (haji) was usual for Indonesian Islamic officials, both for the sake of the pilgrims as well as in the interest of paying visits to important Middle Eastern Muslim leaders. ${ }^{1}$ But for Hamka, the additional travel, especially to Egypt, was unusually significant. This was his first visit to the 'land of the pyramids'. Until then, Egypt had existed only in his mind, serving to embellish his religious imagination as well as his feelings and representations about the greatness of Islamic civilization, as is strongly enunciated throughout his writings, in his fiction as well as his essays on culture and religion.

Hamka was clearly not the first Indonesian Muslim to visit Egypt. Relations between Indonesia and Egypt existed long before Indo-

1 Other examples of officials who made similar journeys include K.H. Masjkur, K.H. Saifuddin Zuhri, K.H. Wahib Wahab, and K.H. Idham Chalid. 
nesian independence and had developed continuously as a result of the presence of Indonesian students in Cairo. ${ }^{2}$ It was thanks to this student network, moreover, that Egypt became the first country to offer recognition of Indonesian independence. By means of its role in the Arab League, Egypt encouraged other Arab nations to recognize Indonesia as well. ${ }^{3}$

These relations were quickly continued in a formal way after international recognition of Indonesian independence, with H.M. Rasjidi becoming Indonesian Ambassador to Egypt and Saudi Arabia and, of special importance, with M. Natsir becoming Minister of Information and then Prime Minister. ${ }^{4}$ When he was Prime Minister, Natsir actively promoted relations with Islamic nations through visits to a number of them, including Egypt and Pakistan. ${ }^{5}$

In my view, however, Hamka gave a new dimension to relations that were initially purely religious and political, adding a cultural nuance to them. Since the 1930s, through the journal Pedoman Masjarakat that he edited, Hamka had become famous for his writings and fictional works that were closely linked to the Islamic world, especially Egypt.

While Hamka's visit to Egypt in 1950 strengthened the cultural position he already held, it also elevated his role in the years to come as a cultural broker between Indonesia and Egypt. This role grew stronger at the end of the 1950s and the beginning of the 1960 s, as a result of his translations and commentaries, as well as the two journals about Islamic culture that he fostered, Pandji Masjarakat and Gema Islam.

Hamka poured his observations and jottings into the book $D i$ lembah sungai Nil (In the valley of the river Nile) (1952), which was published by the firm Gapura, a contributor of additional travel

2 For studies about the situation and role of Indonesians studying in Egypt from the early 19th century to the present, see for example William R. Roff (1970), Mona Abaza (1993, 1996), and Michael Laffan (2004).

3 Read the commentaries of the former activists Ismail Banda (1947) and M. Zein Hassan (1980).

4 Rasjidi had been both secretary and treasurer to the Republic of Indonesia's first foreign diplomatic mission, to Egypt in 1947. The mission to the government of King Farouk, which was led by H. Agus Salim, also included Nazir Dt. Pamuncak, Abdul Kadir, A.R. Baswedan and Rasjidi, an alumnus of Al-Azhar University, who later became Indonesia's Ambassador to Egypt and Saudi Arabia as well as the first Minister of Religion (Soebagijo I.N. 1985:xx).

5 It is worth noting that at this time Masjumi was still a large federated political party serving as an umbrella organization for all Islamic organizations, including NU and PSII. Natsir's foreign trips, both during and subsequent to his time as Prime Minister (1950-1951), were continuously and fully reported in the magazine Hikmah. 
funds for his trip. ${ }^{6}$ In this account, Hamka wrote at length about his impressions and feelings of amazement about Egypt and its culture, together with accounts of his meetings with a number of leading Egyptian authors and intellectuals whom he had known of before only through their writings.

Accompanied by several students and staff members from the Indonesian Embassy, among them Zein Hassan and Fuad Fachruddin, ${ }^{7}$ Hamka met Husain Haikal, for example, a leading Egyptian novelist and writer who had once been the leader of the Liberal Party, which opposed the Wafd Party that was then in power. During that meeting, Haikal suggested that there was a need for translations of Indonesian works into Arabic, and he asked Zein Hassan, a secretary in the Indonesian Embassy, to add a cultural attaché to the Embassy in order to strengthen cultural cooperation. Thaha Husein, a well-known writer and intellectual who at that time served as Minister of Training and Education, was another important figure Hamka met.

Hamka also visited important educational and cultural institutions. He went to Al-Azhar University and was received by Syeikh Al-Azhar, Abdul Majid Salim, Syeikh Abdul Latif Darraz, who was executive director of Azhar, and Prof Farid Wajidi, a well-known intellectual and chief editor of the journal Madjalah Al-Azhar. Stopping by Fuad I University, Hamka met with Prof. Amin Al-Khulli, professor of Arabic literature. ${ }^{8}$

Another important encounter was with Dr Ahmad Amin, who became chairman of the Institute of Arab Culture, which was under the auspices of the Arab League and based in Cairo. Ahmad Amin was known for his books on history, philosophy, and literature. He headed the magazine Ats-Tsaqafah (Culture) and before that an institute for translating works in English and French into Arabic.

6 Gapura was a publishing enterprise owned by Andjar Asmara alias Abisin Abas, a famous journalist and filmmaker before the war. Earlier he had been known as the director of a legendary Dardanella theatre group. For more on Andjar Asmara, see Soebagijo I.N.(1981:212-6 and Ramadhan K.H. 1982.

7 Zein and Fuad were former Indonesian student activists in Egypt who took part in the struggle to bring about recognition of Indonesian independence by Egypt and other Arab nations. Later they both worked for the Indonesian Embassy in Cairo. Fuad returned to Indonesia and was given a job by the Department of Foreign Affairs ' [ . . . ] in recognition by the government of the Republic of Indonesia for our services in the Middle East', according to Fuad Fachruddin's own account (1991:154) of his position.

8 Apart from Haikal and Husein, Hamka also met with the intellectual and writer Abbas Mahmud Aqqad; Fikri Abaza, journalist and chief editor of Madjalah Al-Musawwar, which was published by Al-Hilal press; and Muhammad Ali Alubah, a writer who had once served as Minister of Training and Education. Because of lack of time, Hamka was unable to meet with Taufik el-Hakim, Zaki Mubarak, Hassan Zayyat, among others. 


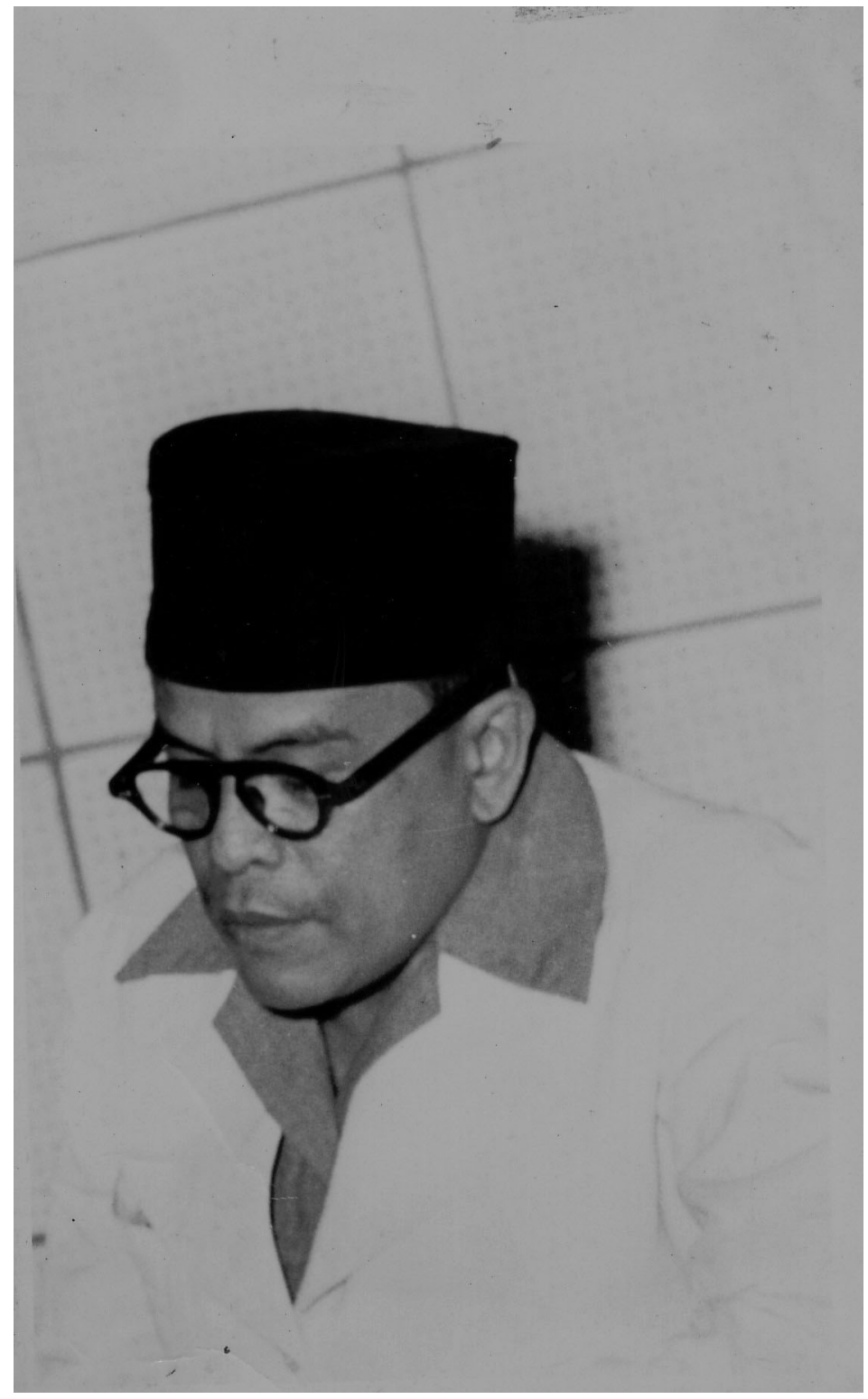

Hamka, 1951. Photo by 'Kempen’. (Pusat Dokumentasi H.B. Jassin) 
Hamka thought that it was important to visit such individuals and their institutions because, as he put it, he too was a member of the Institute of Indonesian Culture (Lembaga Kebudajaan Indonesia, LKI), an organization established by the government in 1948 to assist with formulating the direction of Indonesian culture, which, like the Institute for Arabic Culture, had the convening of cultural congresses as one of its important functions. ${ }^{9}$

These various meetings not only point to the importance of leading Egyptian intellectuals for Hamka, but also Hamka's significance for them. Hamka's visit to Egypt clarified what had been going on inside his head during this time and increased his fascination for the advances in religious and cultural thought taking place in Egypt.

Hamka's admiration for Egypt was well founded. Since the 19th century and the era of Mohamad Ali Pasya, Egypt had been developing and adopting modernizing ideas from the West. Egyptian efforts at translating Western literature and philosophy into Arabic, printing cultural journals, sending students to Europe, and making progress in higher education were famous throughout the Islamic world. With its long history, ancient society, and modern tendencies, Egypt was the most cosmopolitan and modern Islamic nation of the time. For Indonesian Muslims, Egypt in this period was an example of how Islam and progress could be joined together to form an intimate interrelationship.

By means of the Arabic books and journals that came into his hands, Hamka learned about, followed the course of, and was captivated by the progressive movement in Egypt. ${ }^{10}$ Hamka's thinking about nationalism, a resonant concept in this era, was given added conviction by, and was even derived from, Mustafa Kamil, an Egyp-

9 Four years later the LKI merged with BMKN. At the Congress for Indonesian Culture in Bandung, 6-11 October 1951, Hamka was listed as one of nine members of a committee headed by Dr Bahder Djohan, with Soeratno Sastroamidjojo as its general secretary (Nunus Supardi 2007:166-7). It is highly likely that it was Bahder Djohan, who was Minister of Education and Culture in the Natsir Cabinet, who invited Hamka to become involved in the LKI/BMKN. Many of Bahder Djohan's writings about education and culture often appeared in the two magazines edited by Hamka. According to Amura (1977), it was through the BMKN that Hamka recruited young Muslim writers like Sidi Gazalba, M. Radjab, Amura, Amrin Thaib, and others to take an active role in the cultural field. In the debates during these cultural congresses, Hamka always identified himself and was identified as a 'representative' and 'champion' of Islamic culture.

10 Thus it is easy to understand why Hamka (1984:262) was receptive to the recommendation of H. Agus Salim, who was Consul in Mecca at that time, that Hamka forego his intention of studying in Mecca and return to Indonesia, because studying religion in his native land, Salim felt, was superior to studying it in Mecca. Mecca was a place for religious devotionalism, and certainly not, as Hamka imagined, a place for completing the acquisition of modern knowledge and culture. 
tian nationalist activist (Deliar Noer 1983). This is the reason why Hamka made such a conscious effort to introduce the Indonesian public to the cultural life and literature of a dynamic Egypt. In Kenang-kenangan hidup (Memoirs), Hamka (1951:88) wrote, referring to himself in third person as 'Bung Haji' (Brother Haji):

\begin{abstract}
Without ignoring others, it is true to say that Bung Haji was the first to bring the influence of Modern Arabic literature to bear on Indonesian literature. He was the one who first brought Manfaluti here. [...] Because of his fear of being 'left behind', as long as he was in charge of the journal Pedoman Masjarakat he was constantly alert to the progress being made by Arabic literature and culture that was developing in Egypt. ${ }^{11}$
\end{abstract}

It is interesting to note that although Hamka had never studied about or visited Egypt before 1950, he already felt a close affinity to that country. In Di lembah sungai Nil he wrote:

The basis for what I borrowed during the time I was publishing journals, writing books, setting forth my ideas, establishing my perspective on life, and learning about the principles of philosophy, the changes underway in religious thought, even Western literature: it came from Egypt. I read Goethe, Shakespeare, Gide, Carlyle, Anton Chekhov, Gorky, all of them because of Egypt. Even though I had never been there. ${ }^{12}$

In 1931 Balai Pustaka published Hamka's Laila Majnun, which was influenced by an Arabic novel, and in the late 1940s Hamka translated Alexander Dumas (fils)'s La Dame aux camellias (the Indonesian translation was titled Margaretta Gauthier) from an Arabic version of the story.

Hamka obtained the works of Egypt's best-known writers during the 1920s and 1930s, authors such as Mustafa Shadiq, Zaki

11 Boleh dikata dengan tidak melupakan yang lain, bahwa Bung Haji kitalah yang mula2 membawa pengaruh perpustakaan Arab Modern kedalam perpustakaan Indonesia. Dia yang mula2 'membawa' Manfaluti kemari. [...] Karena takutnya akan 'ketinggalan', selama dia memimpin majalah Pedoman Masyarakat, maka senantiasalah dia menuruti kemajuan Kesusasteraan Kebudayaan dan Perpustakaan Arab yang berkembang di Mesir itu.

12 Dasar jang saja ambil seketika mengeluarkan madjalah, mengarang buku2, mengeluarkan fikiran, menentukan garis pandangan hidup, mengetahui dasar2 filsafat, perobahan berfikir dalam agama, bahkan mengenai kesusasteran Baratpun dari Mesir. Saja batja Guthe, Shakespeare, Shaw, Gide, Garlyle, Anton Shikoc, Gorki, semuanja dengan perantaraan Mesir. Walaupun Mesir belum pernah saja lihat. (Hamka 1952:24.) 
Mubarak, Hafiz Ibrahim, Syauqi Bek, Khalil Matran, and Al-Manfaluthi, from the Arabic-language bookstore owned by Salim Nabhan in Surabaya, especially when he visited that city. It is also probable that he acquired books like these by entrusting money to, or receiving presents from friends who had been studying in Egypt. The postal service by sea made this possible at this point in time. Zainuddin Labay, one of his father's students who also taught at Sumatera Thawalib, made frequent use of it. Hamka remembered him because of the size of his private library, a place where Hamka could read literary works in Arabic during his youth.

In actual fact, Hamka was hardly the first person to enter the network of relations between Indonesia and Egypt. His father, H. Abdul Karim Amrullah, had been in charge of the journal Al-Munir which began appearing in April 1911 and had readers among the students and alumni of Al-Azhar. ${ }^{13}$ As suggested by its name, Al-Munir was influenced by Al-Manar, founded by Muhammad Abduh in Egypt. Hamka's father was also a delegate from the Netherlands Indies to the 1924 Islamic World Congress in Egypt. In 1926, he received a Doctor Honoris Causa degree from Al-Azhar. ${ }^{14}$ It is interesting that students from Padang were the dominant group among Indonesians studying in Egypt at that time. Most of them had studied at the school founded by Hamka's father in Padang Pajang, Sumatera Thawalib. It was not surprising, therefore, that Hamka often received supplies of books from his fellow Sumatrans who were studying or working in Cairo. ${ }^{15}$

Hamka's visit to Egypt provided him with a more balanced view of that country and broadened his horizons. He had to admit that

\section{Hamka 1958. For more on Al-Munir, see Azyumardi Azra 1999.}

14 Muchtar Lufti, who studied at Al-Azhar and who had been a student of Hamka's father in Padang, played an important role as the head of the honorary degree committee. Before going to Egypt, Muchtar had been an anti-colonial activist. On the point of being taken into custody, he was offered a hiding place by Hamka's father and then smuggled in disguise to Egypt via Pekan Baru and Malaya. With the help of Indonesian students in Egypt, Muchtar established the journals Seruan Al-Azhar and Pilihan Timur, both of which were anti-colonial and nationalist. 15 For example, according to commentary by Rusydi (1983:94), Hamka's father once was sent the book Qisshatul Adab fii 'Alam (History of World Literature) by Ahmad Amin. The person who sent the book was M. Zein Hassan who worked at the Indonesian embassy in Cairo and in several other Arab countries. According to Rusydi, Zein was a close friend of Hamka's family and the one who sent books to Hamka the most frequently, either at Hamka's request or on his own initiative (interview with Rusydi, 8-2-2009). I think that Zein was not the only one sending books. Moreover, Hamka was a prolific correspondent, writing to friends abroad, including Egypt, such as Emzita (1977), his former secretary in Bukit Tinggi and a former student whom he had adopted as his own son. Emzita later worked at the Indonesian Embassy for the United Arab Republic. Recall as well that one of his novels, the famous Di bawah lindungan ka'abah (1976), which was set in Mecca during the late 1920s, opens with a chapter entitled: 'Letter from Egypt' (see also footnote 7). 
Egypt was a more developed and open society than Indonesia. This is not to say that he was not critical. With respect to the position of women, for example, Egypt, despite having many champions on its behalf, was still conservative, in Hamka's view, as could be seen from the fact that women were still not admitted to Al-Alzhar and were restricted in their access to politics. When he met with women's organizations, Hamka took pride in the fact that Indonesia already had two female ministers, the Ministers of Labor and Social Affairs, a fact that astonished women activists in Egypt. Hamka was also proud of the fact that in Bukittinggi there was a school for women, Dinayah Puteri, established and directed by Rahmah el-Junusiyah. ${ }^{16}$

Following his visit, Hamka became increasingly committed to promulgating Egyptian ideas, education, religion, and culture. For all its strengths and weaknesses, he saw Egypt as the centre of a new age of Islamic resurgence. His perspective had certainly become more critical and balanced. During the 1950s, while serving in the Department of Religion, he helped manage the Masjid Agung Kebayoran (Great Kebayoran Mosque) and was active in the Badan Musjawarat Kebudajaan Nasional (BMKN, Council for Deliberations on National Culture). Apart from this, he continued to scratch away with his pen, becoming a regular contributor to the daily Abadi and a member of the editorial board of the Masjumi journal Hikmah, one of the Islamic publications that had a national distribution during this era. From 1956 on, however, like several intellectuals and writers in Egypt whom he admired, Hamka also became involved in politics and was a member of the Constituent Assembly. He gained this post through his membership in Muhammadiyah, the most important component of Masjumi. Hamka admitted that he wasn't particularly active in politics, merely serving when needed as a 'vote getter' to insure a Masjumi victory. He soon withdrew from the political world. In the words of his wellknown motto: 'The political field is not my arena' (Lapangan siasat bukan medanku).

16 Hamka 1952:99. It is interesting that when he visited Indonesia in 1956, Syeikh Abdurrahman Tadj, Rector of Al-Azhar, visited Bukittinggi and in particular the school Diniyah Puteri, founded by Rahmah. The Syeikh was amazed by the school, the likes of which did not yet exist in Egypt. It was not until 1962 that a similar girls school was opened at Al-Azhar under the rectorship of Syeikh Syaltout. In 1957, Rahmah el-Yunusiyah, known as the 'Kartini of the Islamic movement', was invited to Egypt after she had made the pilgrimage to Mecca. During her visit Rahmah received the highest honorary religious degree awarded by the faculty, the Syeikhah. According to Hamka, this degree had never been granted to a woman before. One result of this honour was that graduates of Diniyah Puteri were sent to study at Al-Azhar on Egyptian government scholarships. See Hamka 1958:265; Aminuddin Rasyad 1977. 
In 1958, after returning home from attending the Symposium on Islam in Lahore, Pakistan, where he was a member of the Indonesian delegation, Hamka continued his journey to Egypt at the invitation of the Egyptian government. On 21 January he delivered a speech in Arabic entitled 'The influence of Muhammad Abduh in Indonesia', on the occasion of receiving the degree Doctor Honoris Causa from Al-Azhar University. The diploma is officially stamped in Arabic: Ustazd Fakhriyah. ${ }^{17}$ The granting of this degree expressed the gratitude of the Egyptian government to Hamka for his work in spreading knowledge about Egyptian culture in Indonesia and serving as an important and prominent cultural 'broker'.

In 1959 Hamka founded the bi-monthly journal Pandji Masjarakat, which announced itself as a journal of Islamic knowledge and culture. In the lead essay published in the first issue, it is stated that Pandji Masjarakat will 'place emphasis on its responsibilities in the area of popular culture and knowledge'. Apart from this, it is hoped that '[the journal's] publication will hasten the birth of a genuine awareness as part of the development of new thought and literature, both of which are important elements in a culture and body of knowledge that are in harmony with the reform and modernization of the true Islam' (Sebab 'Pandji Masjarakat'1959).

Islamic reform and modernization were not entirely new concepts. They arrived in Indonesia in the middle of the 19th century. But the injection of literature and culture into this process was certainly novel, and this is what Hamka repeatedly carried out via Pandji Masjarakat. In the previous Pedoman Masjarakat he published novels in serial form, most of them his own work; in Pandji Masjarakat, he provided space for poetry and short stories, along with essays on culture and general knowledge.

Pandji Masjarakat soon became an important hub of information about Islamic culture in Indonesia as well as the Islamic world. By means of the journal, Hamka assembled Muslim writers and cultural experts to publish articles on culture and science, both locally conceived as well as adapted or translated from elsewhere, especially coming from or about Egypt and Pakistan.

17 Rusydi 1983:6. This speech was later translated into Indonesian and published by Tintamas in Jakarta in 1962. In 1959, Idham Chalid, the young leader of NU from Kalimantan Selatan and alumnus of Pesantren Gontor, Ponorogo, who had close ties to and a degree that was recognized by Al-Azhar, also received a degree of Doctor Honoris Causa from that university. For more on Idham and his connection to Egypt and Al-Azhar, see Arief Mudatsir Mandan (2008). 'Last but not least', Soekarno, who portrayed himself as a leader of world Islam, received an honorary degree in philosophy from Al-Azhar University on 24 April 1960. 
During the short period of its publication, the two years between mid-1959 and mid-1961, every issue of Pandji Masjarakat contained an article from or about thought and the development of the sciences in Egypt. Of course Egypt was not the only Muslim country to be discussed, but it is true to say that conditions and intellectual developments in Egypt dominated the pages of the journal, so much so that it was accused of being an agent for the dissemination of Arab ideas and culture.

Connections with students or other Indonesians in Egypt or to Egyptians in Indonesia strongly supported the development of the journal, especially with respect to editorial decisions. It is known that, personally or via Pandji Masjarakat, Hamka maintained relations with Ali Fahmi Al-Amrousi, Egypt's Ambassador to Indonesia. According to Junus Amir Hamzah (1963), it was Ali Fahmi who arranged for the granting of an honorary degree from Al-Azhar to Hamka. ${ }^{18}$ Another important figure was Dr Mohammad Mahmoud Ridwan, Cultural Attaché at the Embassy of the United Arab Republic in Indonesia at the time. Mahmoud Ridwan was greatly interested in the world of the arts, literature, and philosophy. ${ }^{19}$ It was reported that both Amrousi and Ridwan visited the office of Pandji Masjarakat several times. Hamka and his friends also felt free to pay frequent visits to the Egyptian Embassy in Jakarta.

Another close relationship was with Ahmad Shalaby, a professor at the University of Cairo, Director of the research institute Muktamar 'Alam Islamy, and cultural editor for the newspaper $A l$ Ahram, the largest paper in Egypt. Under a cooperative agreement between Indonesia and the United Arab Republic (UAR), Shalaby was assigned to teach at PTAIN (Perguruan Tinggi Agama Islam Negeri, the state Islamic university, now UIN, Universitas Islam Negeri) Yogyakarta between 1955 until 1961. Shalaby opened a new route for Indonesian students to go to Egypt for further study. Earlier, most Indonesian students enrolled in Al-Azhar; beginning in 1955, at Shalaby's recommendation, a number of PTAIN and Jurusan Pedagogi (teachers' college, now Yogyakarta State University, Universitas Negeri Yogyakarta, UNY) students received Indonesian government scholarships and were sent to study at the Universities

18 Speech by Ali Fahmi Al-Amrousi, 'Revolusionerisme Nabi Muhammad dalam Membina Ummat Baru' (Nabi Muhammad's revolutionary ideas in the building of a new Islamic community), given at the Maulid celebrations in Jakarta, translated in Pandji Masjarakat. See Ali Fahmi Al-Amrousi 1959.

19 Ridwan was in fact a frequent contributor. See, for example, Alam Islamy dizaman depan (The Islamic world in the age to come) (Mohammad Mahmoud Ridwan 1960) and Film keagamaan Islam (Islamic religious film) (Mohammad Mahmoud Ridwan 1962). 
of Cairo and Darul 'Ulum. Apart from teaching, Shalaby also delivered many public lectures, often by radio broadcast. Almost all of his books on the subject of Islamic history and culture were translated into Indonesian; among the translators was Prof Mukhtar Jahja, professor at PTAIN and an Egyptian university alumnus. ${ }^{20}$ Hamka and the Pandji Masjarakat circle also maintained close contact with Syeikh Shaltout, who was made Rector of Al-Azhar in 1958. A year after assuming the leadership, the journal praised the progress that Al-Azhar had made under Shaltout: 'After only a year of his leadership there are many improvements to be felt that will lead to progress. A lot of new energy fills ideas that are progressive ....' Thus wrote the editors of Pandji Masjarakat (Semangat Baru 1960:17).

On a monthly basis the editors of Pandji Masjarakat routinely received issues of Al-Islam and Al-Azhar published by Al-Azhar University. They were also sent a copy of Al-Fatwa, a book containing a compilation of Syeikh Shaltout's responses to questions from the Muslim community, as well as a book of his public addresses in 1959. When the Department of Religion invited Syeikh Shaltout to Indonesia in 1961, he visited the offices of Pandji Masjarakat and the Great Kebayoran Mosque, which Hamka was managing at the time. When he went to the mosque he officiated at its renaming as Masdjid Agung Al-Azhar, a clear reference to the university of the same name. ${ }^{21}$

Hamka resigned as a staff member of the Department of Religion because of a government regulation that prohibited bureaucrats in the ' $F$ ' category from belonging to a political party. Hamka was then prepared to devote himself to the journal Pandji Masjarakat and to help with Masjumi. But in 1960 Mas-

20 Ahmad Shalaby's article (1959) 'Mentjapai masjarakat Islam dalam ikatan ke-Islaman' (Achieving an Islamic society through commitment to Islam). This article was in fact a condensed version of his book, translated into Indonesian as Masjarakat Islam. In the introduction, Ahmad Shalaby (1957:iv) acknowledged that his book was 'inspired by Indonesia [...] an echo of my life there, an echo of my studies with my students, an echo of my lectures to learned young people'. 21 Muhammad Shaltout was the popular Syeikh al-Azhar in Indonesia. Excerpts of his ideas and works on religion were translated into Indonesian; see, for example, Fatwa (1972) by Zaini Dahlan and Bustami A. Gani. During the meeting of the Himpunan Seni Budaja Islam (HSBI, Association for Islamic Arts and Culture) on 15-17 December 1961 in Jakarta, for example, one of the keynote speakers, Al-Ustazd Al-Fadhil Abdullah bin Nuh, quoted a pronouncement by Shaltout in support of the importance of art in Islam. Shaltout was of the opinion that there was no basis in the Quran, the Hadith, or theological analogies (qias) for banning singing or any musical instrument. See Gema Islam 1-1 (15 January 1962):15-6. Sidi Gazalba, a contributor at the HSBI meeting and a prolific writer on Islam and culture, also quoted Abdullah bin Nuh in the section 'The mosque and the arts' of his book Mesjid; Pusat ibadat dan kebudajaan Islam (The mosque; A centre of worship and Islamic culture) (Sidi Gazalba 1962:217). 
jumi was disbanded and outlawed by Soekarno because of the party's alleged involvement with the PRRI rebellion. In that same year, on 17 August 1960, Pandji Masjarakat was banned because it published Mohamad Hatta's 'Demokrasi Kita' (Our democracy), which was critical of Soekarno's Guided Democracy (Mohamad Hatta 1960).

Hamka's field of action grew more circumscribed. During these years he was only active as the chairman of the Majelis Seniman Budajawan Islam (MASBI, Council of Islamic Artists and Cultural Figures), which fell under the direction of the Himpunan Seni Budaja Islam (HSBI, Association for Islamic Arts and Culture).$^{22}$ The problem was that HSBI's sphere of activities grew narrower because it was constantly being linked to Masjumi, which had been declared illegal. One place where Hamka was still free to do as he pleased was the Al-Azhar Mosque, which was located near his home.

Originally called the Great Kebayoran Mosque (Masjid Agung Kebayoran), this mosque was built in 1952. Here Hamka regularly delivered early morning prayer talks (kuliah subuh), attended by a large congregation. As competition with artists on the Left grew more intense, the garden and auditorium of the mosque were much in use for artistic events, art exhibitions, theatrical performances and so forth, especially those organized by HSBI ${ }^{23}$ It is also important to note that the editorial office of Pandji Masjarakat (and later of Gema Islam) was located in another part of the Al-Azhar Mosque building.

In 1962 the Yayasan Perpustakaan Islam (The Islamic Library Foundation) established the magazine Gema Islam, with Lieutenant-General Sudirman as publisher, Colonel Mukhlas Rowi as executive editor, and Rusydi Hamka as managing editor. Listed as members of the editorial board were H. Anwar Tjokroaminoto from the Partai Sarekat Islam Indonesia (PSII, the Indonesian Islamic League Party), H. Mahbub Djunaidi, a reporter and writer from the Nahdlatul Ulama party (NU, the Awakening

\footnotetext{
22 MASBI was the advisory board for HSBI, consisting of cultural authorities and senior ulama. For more on HSBI, see Choirotun Chisaan in this volume.

23 For example, the play Titik terang (Bright spot) by Arifin Yunan was performed in the square in front of the mosque. The biggest theatre event was the performance of the play $D i$ sekitar Maulid Nabi besar Muhammad SAW (Nearing the birthday of the great prophet Muhammad, may the blessings of God and peace be upon him), which was written by Yunan Helmy Nasution, chairman of HSBI, and performed in the open space of the mosque garden on 1 September 1961. According to reports, the performance was attended by 30,000 spectators. One piece of evidence about the colossal size of the performance is the fact that 15 horses were brought on stage.
} 
of Muslim Clergy), and Mahmudah Mawardi, a woman activist, also from the NU. Hamka was mentioned merely as an 'assistant'. In the inaugural edition, General A.H. Nasution's contribution served as an official stamp of approval for two officers under his command to assist Gema Islam as a service to society (Sambutan M.K.N/KASAD 1962).

The motto of the magazine was 'Mengisi dan Melaksanakan Pola Pembangunan Semesta Berentjana' (Fulfill and carry out the blueprint for universal, planned development). An extremely broad and significant slogan! In fact, like Pandji Masjarakat, Gema Islam provided wide scope for discussions of scientific and cultural issues, short stories, and poetry by both Indonesian Muslim writers and those from other Islamic countries. ${ }^{24}$ The same writers contributed to both Gema Islam and Pandji Masjarakat, a fact that shows that the first journal had simply replaced the second.

Hamka contributed a regular column to Gema Islam entitled 'Tafsir Al-Azhar' (Commentaries from Al-Azhar), which he took from the early morning prayer talks that he gave at Al-Azhar Mosque. In addition, he also wrote frequent essays on culture and other subjects. Looking at the editorial staff and the content of the magazine, and taking into consideration all the energy Hamka poured into it, it is clear that he was not simply an 'assistant'. As Rosihan Anwar (1977) acknowledged a few years later, Hamka was really the driving force for the magazine. ${ }^{25}$

Thus in taking over the role of Pandji Masjarakat that had preceded it, Gema Islam became a critical junction in the network of Islamic cultural information within Indonesia and between Indonesia and the Islamic world. One can say that its role extended beyond editorial matters, because the magazine's management clearly reflected the 'cooperation' that was taking place between the military and the community of Muslim cultural authorities and writers. Two names yet to be mentioned, Bahrum Rangkuti and M. Isa Idris, were both men with the rank of Lieutenant-Colonel who were known as activists and writers. Looked at only in terms of the make-up of the editorial board, the magazine shows that all the factions in the Islamic community formed a 'unity', something

24 The inclusion of translations of foreign texts was a conscious choice and considered extremely important, as was noted in the first anniversary issue of Gema Islam: 'We consider works in translation by Islamic scholars from outside Indonesia [...] to be beneficial to the reader', see Gema Islam berusia, 1963:7.

25 Rosihan Anwar, editor of the newspaper Pedoman, which was also banned together with Pandji Masjarakat, wrote the weekly column 'Kronik dan Komentar Islam' (Islamic chronicle and commentary) for Gema Islam, using the pen name Al-Bahist, which was suggested to him by Hamka. 
that was difficult to find in and between political parties. ${ }^{26}$ This was due to the fact that the only thing that created unity there was the spirit of opposition generated by the cultural movement on the Left. One can sense a higher level of contentiousness in the pages of Gema Islam due to the rise in the political temperature at that time. Maybe this fact marks the essential difference between that magazine and its predecessor Pandji Masjarakat. ${ }^{27}$

Apart from short stories, poetry and essays in translation that appeared in Pandji Masjarakat and Gema Islam, there were also translations of works by Egyptian writers and intellectuals. Such translations into Indonesian reflected a different dimension of Indonesian-Egyptian relations. Although most of them were of religious tracts, there were also many literary works: short stories, plays, and novels. From the beginning Hamka played an important role in this regard. ${ }^{28}$

USMAR ISMAIL; OBSERVING EGYPT, VISITING SAUDI ARABIA

In 1959 Usmar Ismail visited Egypt. At that time Usmar was Indonesia's most famous filmmaker. He began his career as an author, writing poetry, short stories, and plays. A. Teeuw (1952:124-30) in particular regards the play Sedih dan gembira (Sad and happy) published by Balai Pustaka (1948) as his important contribution to Indonesian literature. Asrul Sani mentions Usmar as 'someone from the last generation of writers to write or conceive of poetry in the manner of Pujangga Baru'. ${ }^{29}$ 'The history of Indonesian film could not be written without also writing the story of his life; the development of Indonesian film cannot be understood without understanding his ideas', Asrul commented.

26 In the realm of party politics there were frequent disagreements between Masjumi and NU on the one hand and Perti (Pergerakan Tarbijah Islamijah, Islamic Education Movement) on the other. For more on this subject, see Deliar Noer 1987.

27 At the beginning of its second year of publication Gema Islam had a print run of 34,000 copies, compared to 10,000 at its inception. It was planned to raise this number to 40,000 in the second year. According to H.M. Joesoef Ahmad, the publisher, the journal was sent out by mail, so that it could be directly and evenly distributed to all its readers in every corner of the archipelago. See H.M. Joesoef Ahmad 1963:8.

28 For more on the first translations of Arabic literature into Indonesian see further Maya H.T. Liem in this volume and Jedamski 2002.

29 Asrul Sani, 'Sebuah apresiasi' (An appreciation) (1983:11), an introduction to a collection of Usmar Ismail's writings. Asrul Sani (1926-2004) was a poet, essayist, and literary translator, as well as a leading Indonesian filmmaker. Most importantly of all, he provided the inspiration for the 'Surat Kepercayaan Gelanggang' (The Gelanggang Testimonial of Beliefs). For more on Asrul Sani, see Ajip Rosidi 1997. 


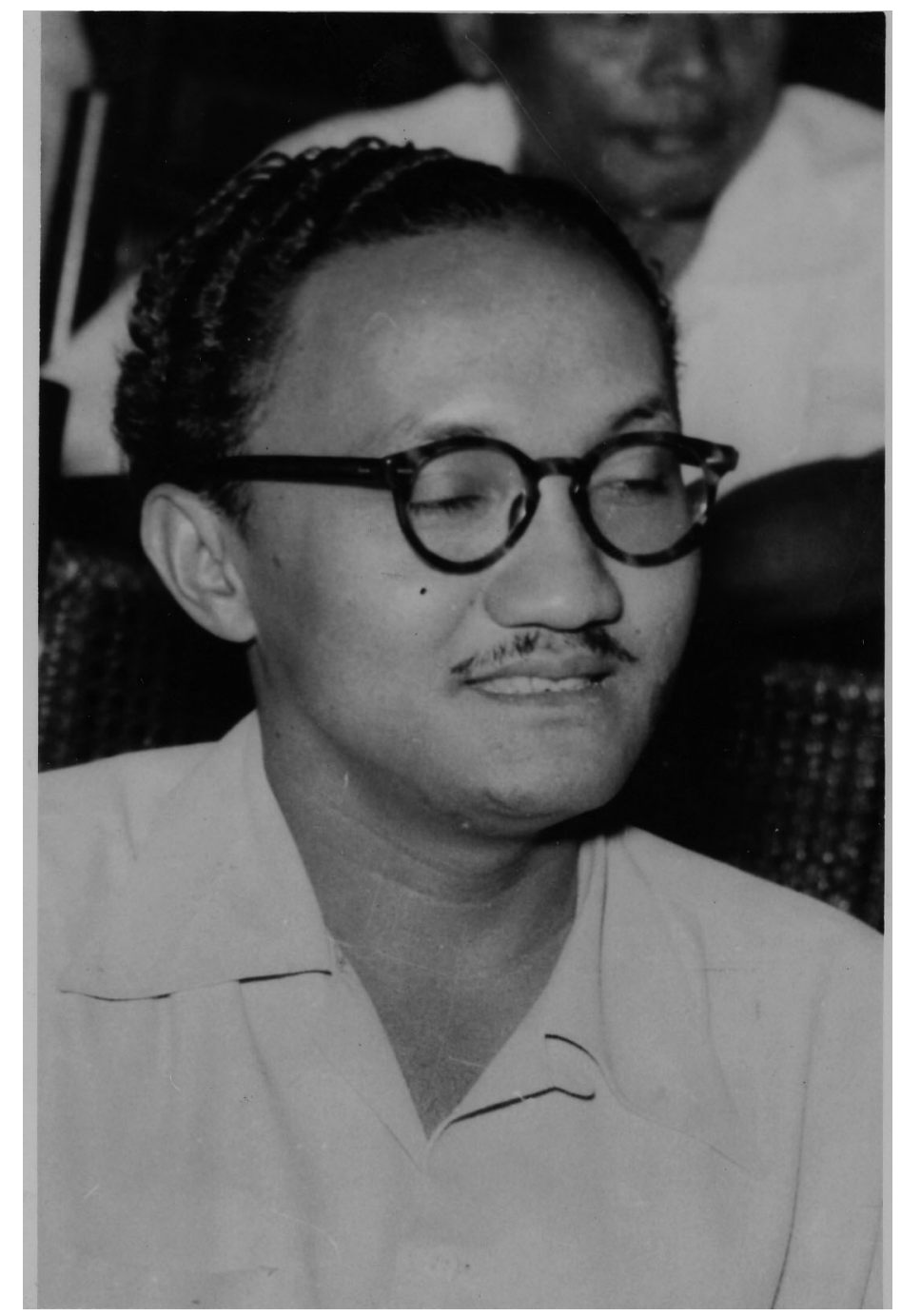

Usmar Ismail in 1949. (Pusat Dokumentasi H.B. Jassin) 
Prior to Usmar there were Indonesian filmmakers, including Anjar Asmara who fought to add an Indonesian style to Malaylanguage films being made in Indonesia. The difference between Usmar and Andjar was that beginning with his film Darah dan doa (The long march), Usmar was the first director to connect his films to national events that concerned the fate of every Indonesian. 'He was a pioneering figure from the first generation of Indonesian filmmakers who entered the world of film with a wider artistic awareness than ever before' according to Asrul. ${ }^{30}$ Because of the way in which he inserted a national consciousness into this film, Usmar became famous as the 'Father of Indonesian Film' and his Darah dan doa is considered the first truly Indonesian film.

As a leading filmmaker, Usmar travelled many times to other countries, especially to the US, Italy, and Japan in order to attend seminars and film festivals. ${ }^{31}$ In my view, however, his visit to Egypt was especially important, because in so doing he revealed another dimension to his vision about film, one that concerned the countries, politics, and society of Islam.

In his essay entitled 'Meninjau industri film di negara Nasser' (Observing the film industry in Nasser's country), published in Harian Pedoman, 23-27 October 1959 in conjunction with his visit to Egypt, Usmar wrote:

For me Cairo was a surprise because I had imagined that I would encounter an Islamic city in the middle ages, where women still wore the veil, with only their eyes visible, where only the sound of praying was heard all day long, where at the most one could enjoy listening to the gambus (six-stringed Arab lute). But such was not the case. Cairo was a modern city, no less modern than Paris, London, or Berlin. Indonesians will be sorely disappointed if they imagine that Cairo is the Islamic city of their fantasies. ${ }^{32}$

30 Asrul Sani 1983:11. Usmar is also recorded as having once been an assistant director to Anjar Asmara. See footnote 6.

31 Usmar made comments about his visits and participation in festivals in a number of publications; these were later collected in Usmar Ismail (1983). For some observations about Usmar's view of America and Hollywood, see Tony Day in the present volume.

32 Bagi saya Kairo merupakan suatu surprise karena tadinya saya mengira akan menjumpai suatu kota Islam abad pertengahan di mana para wanita masih berkerudung dan hanya kelihatan mata mereka saja, di mana hanyalah kedengaran orang berzikir sepanjang hari, atau paling-paling hanya akan dapat menikmati musik gambus, ternyata tidak. Kairo adalah kota modern, tidak kalah modern dengan Paris, London, atau Berlin, dan akan amatlah kecewa golongan Islam Indonesia jika mereka menyangka Kairo adalah kota Islam yang terangan-angan dalam pikiran mereka. This article can be found in the collection of essays by Usmar Ismail (1983:210-1). The excerpts here refer to this edition. 
Usmar's surprise reminds us of Hamka's when he encountered Egyptian 'progress' years before. The only difference lies in the fact that Hamka's surprise was in contrast to his impressions from his reading, whereas Usmar saw Cairo, the capital of Egypt, afresh with his own eyes. Their different educational backgrounds underlie the fact that Hamka's knowledge about Egypt preceded Usmar's.

In the rest of his essay, Usmar expressed his 'fascination' with the Hotel Nile Hilton, a joint Egyptian-American project on the banks of the Nile, staffed with pretty young girls. He was intrigued by the liberal thinking involved in the building of scores of night clubs, including Sahara City, famous for its belly dancers. It was said, writes Usmar, that a visit to this club was a must (fardhu) for Indonesian officials coming to Cairo. And this, he added, was natural given the fact that in Indonesia it was rare to get the chance to watch such a risqué show at a public venue.

It was interesting, according to Usmar, that the world of belly dancing in Egypt and Syria became the central plot line in most Arab films. This was just as true of films with a patriotic theme like Djamila Bouhired as it was of religious ones like Khalid bin Walid, which was funded by the Institute of World Islam (Muktamar 'Alam Islamy). It was not strange, according to Usmar, that thousands of feet of Egyptian film entering Indonesia lay cut into pieces on the office floor of the Board of Film Censors.

Accompanied by Indonesian embassy staff in Cairo, Usmar went to see the two films just mentioned. Djamila Bouhired had come to his attention before his arrival in Cairo, because the story of the film was already popular in Indonesia, having been serialized by Rosihan Anwar in the pages of Harian Pedoman from February to March 1958. ${ }^{33}$ Usmar was curious to see how an Egyptian director would treat a subject that was very much alive in the imaginations of the audience without eliciting inappropriate responses.

33 In his memoir, Rosihan Anwar (1983:195), who edited Pedoman, recalled the story of Djamila Srikandi Alzajair because it was popular with his readers and increased the circulation of the paper he led. The plot revolves around the struggle of a young girl, Djamila Bouhired, as a member of the Algerian Front de Libération Nationale (FLN, National Liberation Front) against the French. Although she was captured and tortured, she refused to surrender and continued to fight on. According to Rosihan, the story was written by Lakdar Brahimi, who became the representative of the FLN in Jakarta and was based on what he had read in newspapers like Le Figaro and l'Humanité. Laskar wrote his story in English, which was then translated by Pedoman. Rosihan Anwar was a close friend of Usmar Ismail's, and together with Abu Hanifah they formed the theatre group 'Maya'. When Usmar went to the United States to study film in 1952-1953, Rosihan took over as head of Perfini. 


\author{
G A L A P R E M I E R I
}

Film terbesar dari revolusi menentang Pendjadjahan oleh Srikandi Aldjazair

"DJAMILAH BOUCHRIED"

Oleh Pengurus Besar Al-Djamiatul Waslijah

Di BIOSKOP CARYA Djalan Gunung Sahari. Tgl. 4 Mei 1962 dịam 19.00

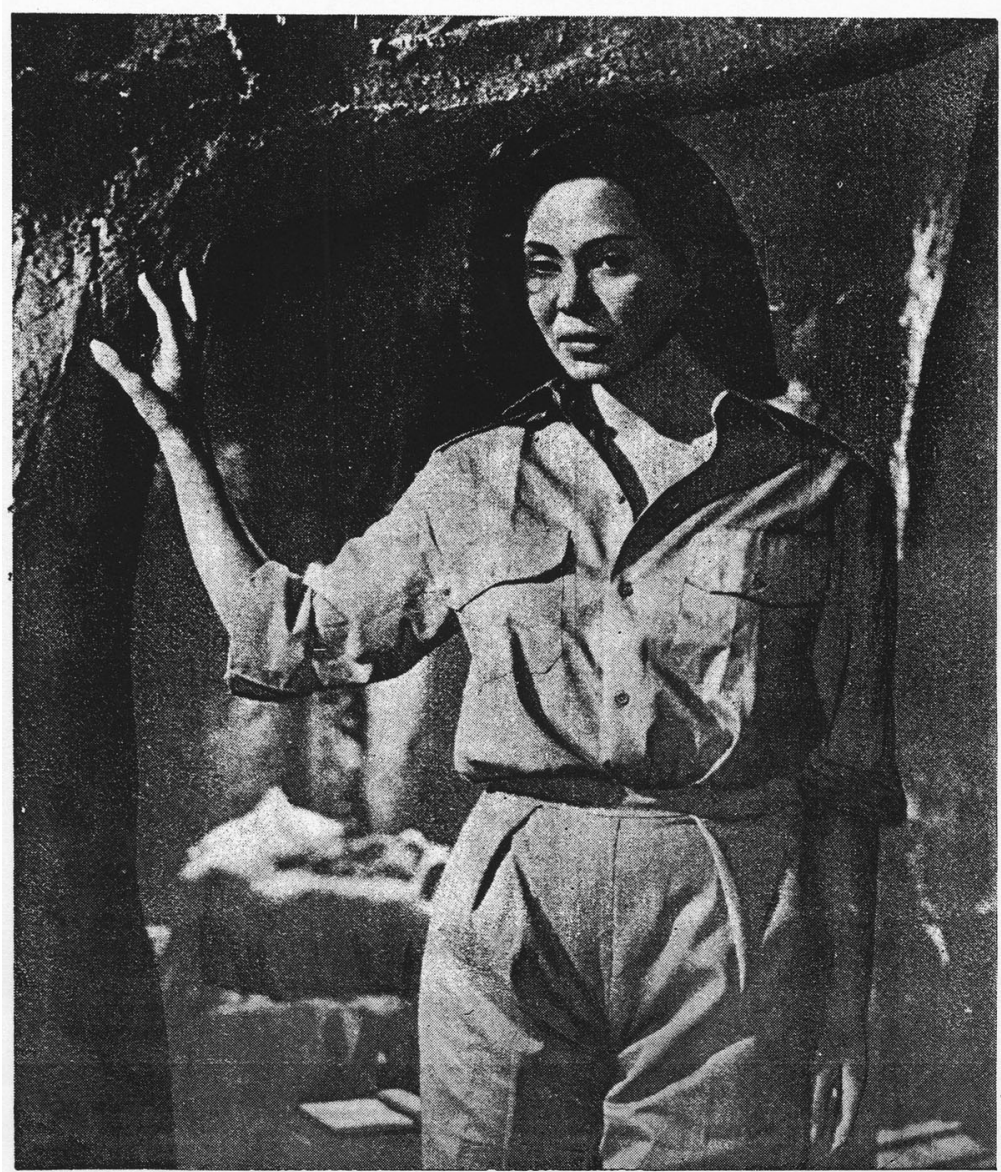

Hasil bersih buat

Santunan Jatim Piatu Al-Washlijah dan Pembinaan Universitas Al-Washlijah.
Penjelenggara GALA PREMIER

Letkol. H. Baharuddin Ali

H. Djafar Zainuddin

Kapten Yunan Helmy Nasution

NF. Iskandar Ishak

Nj. A. Hamzah Nasution

Indonesian poster for the Egyptian film Djamila Bouhired 
Unlike most Egyptian films, Djamila had flow and pace, according to Usmar, and the actors were convincing. Even so, he felt that some of the scenes were too long and unrealistic. He praised the actor Magda who played the role of Djamila, a view shared by the Moscow Film Festival jury that named her the best actress for 1959. ${ }^{34}$

Usmar also had the opportunity to meet Miss Magda, the director of Magda Films, which produced Djamila Bouhired. Miss Magda was the company's lead actor. Their conversations led to a plan to cooperate in the making of a film in either Indonesia or Egypt. In the immediate future, they agreed to have Usmar's film company Perfini make Djamila Bouhired available to viewers in Indonesia.

Meanwhile, the film Khalid bin Walid, which told the story of a heroic figure during the early period of the spread of Islam, was not considered to be on a par with Hollywood films with their spectacular scenes and settings. This was true despite the fact that the film had been made using Technicolor and Cinemascope, making it the most expensive film produced in Asia. Usmar was certain, however, that the film would appeal to the Islamic community in Indonesia because of its theme..$^{35}$ Notwithstanding that fact, he also thought that propaganda for the revival of a pan-Arab state in line with Nasser's political views had been inserted into both films. For an outsider like himself, this message seemed a bit forced.

Usmar (1983:215) summed up his view of Egyptian films by saying that Egyptian films still conveyed an aura of religious poetry (kasi$d a h)$ and belly dancing. Yet, despite the fact that Egypt was known as a centre of Islamic culture throughout the world, its films contained sex scenes featuring kissing and cruelty. This appeared to be perfectly allowable in the Egyptian context. Indonesia, on the other hand, was at that moment undergoing a process of self-censorship, involving the elimination of all kinds of cultural excesses. According to Usmar, this made Indonesia a more mature location for a world centre of religion.

During these years, the world of Indonesian film was beset by various problems ranging from insufficient funds and limited government-run facilities, to domination by imported films. These issues should have been the concern of the film industry alone. But they became entangled in politics - the struggle to recover West Irian, the PRRI regional rebellion involving both the Masjumi and PSI (Partai Sosialis Indonesia) political parties, the British colonial

34 At the same festival Usmar's film Pedjoeang (Fighter) won the prize for the best actor, for the role played by Bambang Hermanto.

35 Khalid bin Walid was one of the few Egyptian films to be distributed and shown both in commercial theatres as well as at the Cultural Centre of the United Arab Republic in Jakarta. See Mohammed Mahmoud Ridwan 1962. 
presence on the Malay Peninsula - with the result that controversies in the film world became political ones. The politics of film followed the international political trends of the cold war and divided along two opposing blocs (Salim Said 1979).

Usmar did not occupy an advantageous position in this political situation. He had been the first Indonesian to study film at UCLA (The University of California Los Angeles), funded by the Rockefeller Foundation, in 1952-1953. On his return to Indonesia, he made films in which he was much concerned with matters of film aesthetics. Because of his American credentials, he was asked by the Rockefeller Foundation to recommend suitable candidates for scholarships to study in the US. Usmar took a number of his films to international film festivals abroad. With his American ties, his involvement with film festivals held in 'capitalist bloc' countries, and especially because of a number of his films that were deemed to be 'anti-revolutionary', Usmar was accused of being a fellow-traveller of the PSI and a lackey of the Americans. ${ }^{36}$

The 'penutupan studio' (closure of the studios) affair (1957), which involved Usmar, Djamaluddin Malik and the Association of Indonesian Film Companies (Persatuan Perusahaan Film Indonesia, PPFI), further dragged him into the vortex of political conflict. The affair originated from the government's failure to monitor the film industry, so that imported films, especially from India, pushed locally made movies out of the market, while local studios were threatened with bankruptcy because capital was no longer available for making films. However, the Union of Film Workers (Sarekat Buruh Film, Sarbufi), which had ties to LEKRA, refused to go along with the decision to close the studios. Instead, they proposed the banning of American films and a government take-over of the affected studios. Even more threateningly, they accused the American Motion Picture Association of Indonesia (AMPAI), which distributed American films in Indonesia, of being behind the move to close the studios. ${ }^{37}$

I believe that Usmar's visit to Egypt must be considered in the light of these events. As someone who had long been mesmerized by Western ideas and modes of expression - starting from the time he plunged into theatre until his immersion in the world of film Usmar's decision to visit Egypt is very significant. It seems to suggest an important shift in his view of his artistic practice. Examined carefully, however, this shift had nothing to do with aesthetic pressures: its origins were political.

36 See Misbach Yusa Biran 2008:116-7; Usmar Ismail 1983. For more on Usmar's Rockefeller grant and impressions of Hollywood, see Tony Day in this volume.

37 See Usmar Ismail 1983:91-7; Misbach Yusa Biran 2008:157-69; Salim Said 1991:74-92. Compare Rhoma D.A. Yuliantri and Muhidin M. Dahlan (2008:201-75), especially chapter 5 on film. 
If we consider the film Djamila, for example, Usmar (1983:213) states that he was motivated by the 'desire to see how Egyptian directors processed events that were still fresh in the minds of the viewer without giving rise to unwelcome reactions'. Clearly, this aim reminds us of the problems he was encountering in his own country. Like Djamila, Usmar's films took up the theme of heroism. The difference was that his treatment of heroism was more realistic. But because this was the case, his films Darah dan doa and Enam djam di Djogja (Six hours in Yogya), which 'processed events that were still fresh in the minds of the viewer' failed to find a receptive audience. In the first film it was felt that Usmar exaggerated the role of the Siliwangi Division and portrayed the Darul Islam supporters (Indonesian Islamic State from the Arabic dar al-Islam), and Indonesian Islamic Army (Tentara Islam Indonesia) as traitors. In the second, he didn't present a representation of revolutionary fervour since he included the Dutch army in the story. Both films had to go before the censors and were attacked in the media, especially by the Left. ${ }^{38}$

In his treatment of reality in these two films, Usmar was not dealing with aesthetic issues, but political ones. He sought freedom to create. Censorship, on both political and moral grounds, acted to inhibit creativity. It is apparent that Usmar thought that the politics of Egyptian films were rather ideal. In actual fact, the inclusion of scenes in Egyptian movies where men and women were intimate with one another, which in Indonesia tended to be thought of as 'forbidden', offered wide creative possibilities. On the subject of how politics entered into the themes of Egyptian films, it is true that Usmar complained about the amount of political propaganda in them, something that he found repugnant.

Usmar's journey to Egypt, and his intention of collaborating with Egyptian producers in making movies, was therefore more of a political response than an aesthetic quest. The choice of Egypt was no accident. On the one hand Egypt was a nation whose people were Muslim and was an important exponent of the international Afro-Asian movement. On the other hand, Egypt possessed a strongly socialist but anti-communist ideology. And in addition, Egypt, of all the world's Muslim nations, was synonymous with progress. Turning toward Egypt was a tactical political move that was at once pro-Islam, anti-imperialist, in solidarity with the Afro-Asian anti-colonial movements, and pro-socialist, but not pro-communist.

38 Similar accusations of not being revolutionary were later experienced by Usmar's colleagues at Perfini when they made films about the revolution, like Djaduk Djajakusuma, director of Embun (Dew, 1951), and Asrul Sani because of his Pagar kawat berduri (Barbed-wire fence, 1961). See Usmar Ismail 1983:53-66. 
Moreover, Egyptian films were already reasonably popular in Indonesia. During this period films from Egypt and Pakistan entered Indonesia via an importer by the name of Ridwan P. Lubis. ${ }^{39}$ According to the cultural attaché of the Embassy of the United Arab Republic in Indonesia, Dr Mohammed Mahmoud Ridwan (1962), several Egyptian films were circulating and being shown in both commercial theatres and at the Cultural Centre of the United Arab Republic Embassy in Jakarta itself. In his notes about films circulating during the 1950s, Ridwan finds that Egyptian films were among the imports Indonesians watched. Since the 1930s, in fact, according to Hamka (1952:128-31), Egyptian movies were being shown in Indonesia.

The difference between the reception of films from Egypt compared to that of literature, however, was that Egyptian movies had a bad name. Hamka, for example, thought that Egyptian movies were of extremely low quality and full of obscenity, even though they had been cut here and there by the Board of Censors. 'Ten times worse than dance films from America', he wrote (Hamka 1952:130). Because of his concern about the obscenity issue, Hamka admitted that he once sent an article to an Egyptian magazine in which he explained what a bad impression Egyptian films of this type were making on the Indonesian public. ${ }^{40}$

When he visited Egypt for the first time in 1950, Hamka had another opportunity to watch Egyptian movies. His impression didn't change a bit: Egyptian films were worthless and 'dirty', not fit to be shown in first-class theatres, but only in second- or thirdclass ones. This time Hamka sent a letter of concern to the Egyptian Minister for Education and Culture. 'Egypt should improve the quality of its films because Egypt is still honoured as the "centre" of the Islamic revival in modern times', he wrote.

While Hamka praised Egyptian literature to the skies, he felt nothing but contempt for Egyptian films. Usmar formed exactly the same impression during his visit to Egypt. It is thus impossible that Usmar would develop a new interest in Egyptian movies on purely aesthetic grounds.

39 I encountered this name in a book by Aboebakar Atjeh (1957:259). Lubis was mentioned as being a friend of Djamaluddin Malik.

40 A similar view was expressed by Abu Ubaidah (pen name of Moh. Dimyati) who wrote a weekly column, 'Dari sahabat ke sahabat' (From one friend to another) for the magazine Hikmah. According to him, 'Film-film Mesir yang di-impor ke Indonesia $80 \%$ film tjabul yang kadangkadang lebih tjabul dari film Hollywood' ( $80 \%$ of Egyptian films imported to Indonesia are obscene and sometimes more so than Hollywood movies (Abu Ubaidah 1952:21). According to Hamka (1952:130), Rosihan Anwar, writing for the daily Pedoman, also thoroughly criticized the quality of Egyptian films. As a reporter for that paper, Rosihan visited Egypt in 1952 and wrote extensively about that country, as shown by the many articles on the subject appearing in Gema Islam. 
In any case, Usmar's visit to Egypt was an early sign of his political shift to Islam. This shift led to his involvement with Nahdlatul Ulama (NU), particularly via his support for its cultural affiliate, The Institute of Indonesian Muslim Artists and Cultural Figures (Lembaga Seniman Budajawan Muslim Indonesia, LESBUMI) in 1962. It appears that Djamaluddin Malik, Director of the Indonesian Artists Inc. (PERSARI), Usmar's friend but also competitor in the making of movies, played a role in recruiting Usmar to the Islamic cultural cause. ${ }^{41}$

But it is clear that this was not an easy choice for Usmar. From the beginning of his artistic career, Usmar preferred to be a free agent without any kind of political allegiance. He loved his profession of artist. In this he differed from his two friends Rosihan Anwar and Abu Hanifah who had together founded the theatre group Maya. Usmar didn't join Rosihan Anwar in devoting himself to the world of journalism, even though he had earlier distinguished himself as a journalist. But because he wanted to pour himself into his artistic activities, he resigned his chairmanship of the Indonesian Journalists Association (Persatuan Wartawan Indonesia, PWI) in February 1947 after nine months (Soebagijo I.N. 1981:549-53). He was also not tempted to follow in the footsteps of his friend and older brother Abu Hanifah, who joined Masjumi and went on to have a career as a diplomat. ${ }^{42}$ Yet, times had changed and were forcing him to choose: he turned toward Islam.

Usmar's idea of making a movie in cooperation with the Egyptian company Magda Film never came to fruition. Negotiations failed over the issue of the story, according to him. The plan to show Djamila Bouhired in Indonesia went ahead, although three years behind schedule. The important thing was that, in the case of this film, Usmar was able to showcase an Egyptian movie of quality. ${ }^{43}$

41 Supporters of both Usmar Ismail and Djamaluddin Malik called them the 'dwi tunggal' (duumvirate) of the national film industry. On their relationship, see Ramadhan K.H. and Nina Pane 2006:115-50.

42 On Abu Hanifah, see Ohorella 1985.

43 The premier of this film was shown by the Board of Al-Jami'atul Washlijah at the Carya movie theatre, Jalan Gunung Sahari, Jakarta, on 4 May 1962 at 7 pm. It was stated in the newspaper announcement of the premier, which filled the full back page of the edition of Gema Islam for 1 May 1962 together with a black-and-white portrait of the beautiful Magda dressed as the revolutionary fighter Djamila Bouhired, that the net profit from ticket sales would be donated to orphans receiving Al-Washlijah assistance and to the construction of Al-Washlijah University. Also mentioned were the organizers of the opening night: Letkol H. Baharuddin Ali, H. Djafar Zainuddin, Kapten Yunan Helmy Nasution, Nj. Iskandar Ishak, and $\mathrm{Nj}$. A. Hamzah Nasution. Both Usmar and Rosihan were instrumental in promoting the movie. It should be noted that in addition to being a director and movie producer, Usmar, working through Perfini, had become a film importer, as A. Rahim Latief has pointed out in Ramadhan K.H. and Nina Pane 2006:154-6. 
It was with the government of Saudi Arabia that Usmar did in fact cooperate in producing a film. With the sponsorship of LESBUMI, Usmar participated in making the film Tauhid (Unity) in 1964, shot in Mecca. ${ }^{44}$ Tauhid had an Islamic theme, but it also expressed the revolutionary ethos of the time, as requested by President Soekarno. In remarks at the ceremony in honour of his departure for Mecca, Usmar expressed the hope that the film he was about to make would 'fulfil the President's expectation that it would make a positive contribution to furthering the Indonesian revolution' (Usmar Ismail 1964). In the Islamic context, the film had to reflect the 'flame of Islam', to use an expression taken from the book by Syed Ameer Ali that Soekarno was always quoting. Asrul Sani wrote and directed the film, which was produced by Djamaluddin Malik, with Usmar serving as technical advisor.

Tauhid was made with financial support from the Departments of Religion and Information. Salim Said (1993:80) writes that it was part of a government plan to produce 50 Indonesian films a year, with government-owned banks and companies to provide support to the movie industry. Such government assistance came at a price: the final products naturally reflected the government's views. ${ }^{45}$

It is noteworthy that the Minister of Religion at this time was K.H. Saifuddin Zuhri, while the Indonesian ambassador to Saudi Arabia was K.H.M. Ilyas, Saifuddin's predecessor as Minister of Religion; both were leading figures in NU. ${ }^{46}$ As Misbach Yusa Biran, who was the assistant director for the film, has written in detail in his memoirs, it is hardly surprising that the facilities provided to the film crew were more than satisfactory (Misbach Yusa Biran 2008:181-6). Three of the production vehicles had official Saudi plates, which meant they could go anywhere. Filming could take place freely anywhere at all. Misbach also observed the ease with which Djamaluddin Malik and Usmar Ismail went in and out of the Indonesian embassy in Saudi Arabia.

44 The title of the film was sometimes called Panggilan tanah sutji (The call of the holy land) or Panggilan Nabi Ibrahim (The call of the prophet Ibrahim). Asrul Sani wanted to title the film Tjatatan seorang musafir (Notes of a wanderer).

45 Apart from Tauhid there were many other films that were made as joint government-private ventures. Tauhid has received the most attention, however, because of the involvement of leading figures from the film industry as well as the Saudi government.

46 According to Saifuddin Zuhri (1986:518-9), Tauhid was made at the initiative of these two men, with the agreement of Djamaluddin Malik and Usmar Ismail. In conjunction with Tauhid, Misbach Yusa Biran made an instructional film on the haj. 
Official Saudi support, in the form of permission to film almost everywhere, was indeed remarkable. Saudi Arabia was the most puritanical Islamic nation at this time, banning all forms of artistic expression. In his press release about the making of Tauhid, Asrul Sani talked about the difficulty of arranging for filming at the Masjid Haram in Mecca and the Masjid Nabawi in Medina. 'Part of the filming that had to be made at the two mosques could not take place', he said, 'because certain Saudi officials were afraid that this would cause a stir in some religious circles. ${ }^{{ }^{47}}$ Yet the fact that any kind of permission was obtained at all is interesting and significant, since Saudi Arabia regarded Indonesia as a country that leaned too far to the side of the communist bloc. ${ }^{48}$

Tauhid would have been made in 1963 but filming was postponed until the following year because of problems with obtaining permissions in Indonesia. This turned out to be a blessing in disguise for Usmar Ismail whose relations with artists on the Left were getting worse and worse at this time. ${ }^{49} 1964$ was the year of the third Afro-Asian film festival, held in Jakarta, for which the Indonesian organizing committee and delegation were dominated by the Left. Usmar and Asrul Sani intentionally went to Mecca to make Tauhid and thereby avoid attending the film festival.

Tauhid, along with Anak-anak revolusi (Children of the revolution, directed by Usmar Ismail) were later shown as the Indonesian entries for the film festival that took place in Jakarta as part of the first conference on Afro-Asian Islam in 1965. A number of other films from Islamic nations participating in this conference, such as the United Arab Republic, Iraq, Algeria, Pakistan, Syria, Lebanon, and others, were also shown in first-class movie theatres in Bandung and Jakarta during the festival (Gema K.I.A.A 1965).

47 Antara 12-5-64, as quoted in 'Kronik' Gema Islam (3-51 (1 June1964):4). It is worth noting that two years earlier the National Directorate of Film (DPN) sent two filmmakers, Amura and Djohardin, to Saudi Arabia to make a documentary entitled Perbaikan perdjalanan hadji 1963 (Improvements to making the haj in 1963). The film was completed 'thanks to assistance from the government of Saudi Arabia in the form of every kind of facility and personnel, together with the staff of our embassy'. See the review of this film by Indonesia O'Galelano 1964.

48 Mohamad Ilyas, Indonesian ambassador to Saudi Arabia, Yemen, and Oman at this time, often encountered serious difficulties because of Saudi views regarding Indonesia's Left-leaning tendencies, while at the same time Indonesia saw Saudi Arabia as being reactionary. See Saifullah Ma'shum 1994.

49 To a certain degree, this conflict opened up personal problems. Read the debate between Usmar Ismail and Sitor Situmorang in Taufik Ismail and D.S. Moeljanto 1995. 
According to Misbach Yusa Biran, Tauhid was heavy going for the average moviegoer, with the result that it was not widely shown. An additional problem was that 1965 was a year of nonstop political turbulence, with an evening curfew imposed at $6 \mathrm{pm} .{ }^{50}$

Perhaps the significance of the film, however, lies not just in the final product, but in the networking process by which it was created. Within Indonesia this creative network involved cooperation between Muslim artists and cultural leaders; abroad, it extended out to include the government of Saudi Arabia. ${ }^{51}$ At the very least the film was useful in once again introducing the world of film to Muslim social groups. The collaboration with Saudi Arabia established a precedent that has yet to be repeated.

BAHRUM RANGKUTI: PROMOTING IQBAL FROM PAKISTAN

When Hamka made his pilgrimage to Arab countries in 1950, he visited Karachi, Pakistan on the way. There he met up with Bahrum Rangkuti, a young Muslim writer who was at that time cultural attaché at the Indonesian embassy in Karachi.

Bahrum was born on 7 August 1919 in Galang, Riau and was known as a poet, short-story writer, and dramatist. Since the 1930s his work had been appearing in Pandji Poestaka, Pantja Raja, Gema Suasana, Indonesia and Poedjangga Baroe. He also translated Sophocles's Antigone (1948) and works by Alexander Pushkin (1949). To his friends and acquaintances he was known as a cosmopolitan man who had mastered nine languages: English, French, German, Dutch, Arabic, Farsi, Javanese, as well as his local dialect (Jakob Oetama 1963).

That being the case, what was his connection to Pakistan? Pakistan was a new nation but an old people with an ancient tradition and history. Pakistan's culture was a synthesis of world cultures: Persian, Arab, Greek, not to mention Indian, all of which arrived as a result of economic, political, and religious factors. Pakistan possessed a rich cultural heritage that was visible in its literature,

50 Email message from Misbach Yusa Biran, 7-2-2009.

51 According to Misbach Yusa Biran (2008:214) the film-making network also included several members of HSBI. The farewell party for the film crew at Djamaluddin Malik's house before the departure for Saudi Arabia was attended by many groups of Muslim artists and cultural figures. Usmar Ismail was said to have exclaimed with emotion: 'Never before has there been such a tightly knit group of Muslims in the cultural field.' 


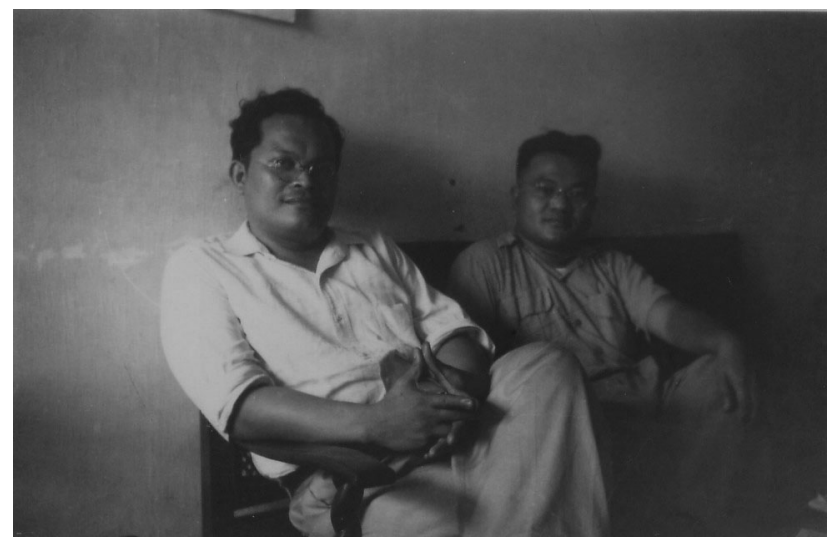

Bahrum Rangkuti (left) with H.B. Jassin, 1952. (Pusat Dokumentasi H.B. Jassin)

music, and architecture. Its traditions of Islamic thought, expressed through the Urdu and Farsi languages, were rich and different from that of the Middle East.

When Pakistan was still part of India, its Islamic identity was not apparent in an international sense, obscured by the dominant Hindu Indic cast of the national culture. But once it had broken away to form its own nation-state, Pakistan's Islamic identity, which had developed in the region of Bengal, burst forth. Pakistan backed Indonesia in its struggle against the Dutch in 1948-1949, forbidding Dutch ships and aircraft from landing in Pakistan. In 1951, Pakistan hosted the Third World Muslim Conference, a gathering that had not been held since before World War II. In that same year, Indonesia and Pakistan signed an official agreement of cooperation (Ahmed Ali 1951; Amal Hamzah 1952).

All of these reasons underlay Pakistan's relations with Indonesia. Natsir made his visit to Pakistan in 1952 a top priority, second only to a trip to Egypt. ${ }^{52}$ In April 1954, the magazine Hikmah sent its reporter Adnan Syamni to Pakistan to write an exclusive on the development of Islam in that country (Adnan Syamni 1954). It is not surprising that Hamka made periodic visits to Karachi from this period onward or that Bahrum spent a year in Pakistan for study and spiritual retreat.

52 Natsir's speech in Karachi was published in serial form in Hikmah 5-20, 21, 22, 23, and 25, (17, 23, and 31 May 1952 and 7 and 14 June 1952). This was of course not the first Indonesian contact with Pakistan. Religious connections, especially in Ahmadiyya circles, existed since the 1920s. See Iskandar Zulkarnain 2005. 
In his first of several reflections on Pakistan written during the year he spent in the 'land of the crescent moon' (as he called it) and published in successive issues of the magazine Zenith, Bahrum touches on his meeting with Hamka and discusses his astonished impressions of Pakistani film:

Speaking of Pakistani film, this offers a truly unusual picture of life to the inhabitants of Karachi and Lahore. Each of these cities has scores of cinemas and (Dear Reader, don't be shocked!) every film runs for months at a time. It is not unusual for movies like Mahl (Palace) and Suraiyya to be shown for 56 weeks at the Nishad theatre in Karachi [,] a period of time that is named accordingly: 'The Golden 56th Week'. At first I was rather puzzled by the fact that any film would be shown this long in movie theatres in Pakistan, no matter how good it was. Then I went to see Mahl for myself, a film starring Madhubala and Ashok Kumar.

Wonderful and beautiful! There are not many Asian films that can express beauty and approach the status of literature like this one. Astonishing that a country that, by Indonesian standards, does not allow women their freedom has succeeded in producing women actors who are exceedingly uninhibited and pleasing in their manner of acting and movement. Every character that is performed, each personality that struggles within itself or against others, the aesthetic atmosphere, and the level of religious and philosophical observation are underwritten by an ancient Indian story, and all of this is assembled by means of good directing and clean visual and sound recording, by means of which the natural and spiritual elements in the film give rise to a feeling of 'respect', making me rather jealous of the successes of films from Pakistan and the West, compared to my memories of Indonesian movies. ${ }^{53}$

53 Ngomong-ngomong tentang pilem Pakistani, memang gambar hidup salah satu keluarbiasaan bagi penduduk Karachi dan Lahore. Setiap kota ini berpuluh-puluh cinemanja dan (djangan terkedjut para pembatja!) setiap pilem lamanja diputarkan berbulan-bulan lamanja. Bukan suatu keanehan kalau pilem sebagai Mahl (Istana) dan Suraiyya berputar sampai 56 minggu dibioskop Nishad di Karachi sehingga peristiwa begitu disebutkan dengan nama; The Golden 56th Week. Mula-mulanja aku merasa heran djuga, apa sebabnja sesuatu pilem begitu lama diputarkan dibioskop-bioskop di Pakistan, walaupun bagaimana bagusnja pilem itu. Lalu aku sendiri pergilah melihatnja, jakni pilem $M a h l$ jang ditafsirkan oleh bintang pilem Madhubala dan Ashok Kumar.

Adjaib dan indah! Tidak banjak pilem Timur jang dapat menjatakan keindahan dan mendekati kesusasteraan begini. Adjaib, bahwa negeri, dimana - menurut ukuran Indonesia - tak ada kebebasan kaum wanita dapat menghasilkan pemain2 pilem wanita jang amat lepas dan sedap gaja main dan gerak-geriknja. Watak demi watak jang diperlakukan, pribadi demi pribadi jang berdjuang kedalam batinnja dan keluar, rasa aestetika, nilai2 agama dan tindjauan falsafat, didukung oleh kissah India purba, semuanja ini dengan regi jang baik dan sound-technik beserta opname jang terang, dimana suara anasir-anasir alam-njata dan alam-rohani menimbulkan rasa "ontzag", membuat aku agak tjemburu kepada hasil2 pilem di Pakistan dan Bharat, djika aku teringat kepada pilem2 Indonesia. (Bahrum Rangkuti 1951a:229.) 
It is uncertain how extensive Bahrum's knowledge of film around the world was, allowing him to praise films in Pakistan to this extent. But at the very least he was knowledgeable about the history of Indonesian film, in comparison with which Pakistani movies appeared to be of higher quality.

It was only in 1950, at least according to the 'official film history' that the first real Indonesian film, namely Usmar Ismail's Darah dan doa, (The Long March) was in the process of being made. This movie received accolades primarily because it was the first time that a film made explicit reference to national events that involved the fate of the entire Indonesian people. But even though Usmar is described as the pioneer of a new generation of Indonesian filmmakers who joined the world of film with more artistic awareness than ever before, it remains true that these early films are considered to fall short of achieving the same aesthetic standards as those found in literature from the same period. It is interesting that Bahrum was struck by the beauty of Pakistani movies, which he felt had achieved the status of literature.$^{54}$ In his account of his visit to Pakistan he describes watching the movie Madhubala with Hamka, who was only able to exclaim 'masya Allah' (Good heavens!), amazed as he was at the beauty and music of the film. Bahrum published his account in the pages of Zenith, a prestigious cultural journal of that period. Unfortunately, Bahrum's writing seems to have no influence on the world of film in general at that time..$^{55}$

Indeed, Bahrum's main interest during his year-long visit to Pakistan lay elsewhere. In many respects he was most absorbed in the realm of cultural ideas. Before he joined the staff of the Indonesian cultural attaché in Karachi, he was in fact, as he put it, 'washed ashore' in Rabwah, (then) a small village on the banks of the Chenab River in Punjab founded by the Ahmadiyya Muslim community in 1948 as a training site for Muslim missionaries. Bahrum described the location as 'a sandy wasteland, circled by rocky

54 Before Partition (1947), Mumbai (formerly Bombay) was the filmmaking capital of the region, with only a few studios located in Lahore (now the capital of the Pakistani state of Punjab and the second largest city in Pakistan). Many of these studios collapsed in 1947, and film production in the ensuing years was minimal: 1948 (1 film), 1949 (6 films), 1950 (13 films), and 1955 (24 films); see 'Film Pakistan', Hikmah, Lebaran issue (1 May 1957):38. Pakistani films, like films from Egypt, were imported into Indonesia at this time, though in a lesser number. For a photo of the Pakistani film actor Mussarat Nazir, see Pandji Masjarakat 5-1 (15 April 1959):10. Unlike Egyptian movies, in general Pakistani films were considered to be respectable and of good quality, according to Amura (1962:8) 'Not all the dance films were improper or spiced up with sexual elements. For example, films from ... Pakistan'.

55 Together with his article are reproductions of paintings from two Pakistani artists, Zubeida Agha and Zainal Abidin, together with a photograph of a Kasmir women's dance. No explanation is given about this, but probably these pictures were supplied by Bahrum himself. 
mountains without names. Here life is extremely simple. There are no urban services and accommodation, and visitors arrive in droves, squeezing into every corner. There are only 212 inhabitants. The houses are made out of mud that has been dried in the sun $[\ldots]$ and the lighting consists of candles and hanging lamps. ${ }^{56}$

The school, rather like a pesantren, in Rabwah was called Jamiatul Mubasheren, established to train Ahmadiyya missionaries from all corners of the world. But Bahrum himself did not want to become a missionary. His own memories of the school dwelt on its library with its rich collection of poetry, Hadith, commentaries, theological treatises, and classical philosophical works by Islamic authors like Sa'adi. Omar Khayyam, Shibili, Al-Biruni, Ibnu Sina, and others. The library also contained Western philosophical writings by such thinkers as Kant and Nietzsche, histories of Europe, as well as the latest magazines and journals. Sir Chaudhry Muhammad Zafrullah Khan (1893-1985), a leading Ahmadi Muslim and Pakistan's first Foreign Minister (1947-1954), studied at this school and visited there twice during Bahrum's stay in Rabwah. Bahrum remembers being impressed by Zafrullah's knowledge, piety, intelligence and self-discipline..$^{57}$

Bahrum's journey to Pakistan was an important intellectual and spiritual pilgrimage for him, especially the six months he spent in Rabwah. There he immersed himself in books on philosophy, literature, and religion that filled him with inspiration. In his account of the journey, which he wrote in the form of letters addressed to a friend he called 'Bung' (brother, mate, comrade), he wrote about ideas, Western, Indian, as well as Islamic. The important aspect of this exposition is the feeling of dialogue and encounter it conveys, of give and take, of mutually confronting influences between these three traditions and ways of thinking. It was emphatically the case that, in Bahrum's view, Islam in Indonesia had to mine Muslim intellectual traditions to the fullest extent in order to acquire the resources for achieving modernity. Of the thinkers he studied and discussed, none

56 According to Bahrum there was one other Indonesian in Rabwah at the time, namely Supardja, the director of Neratja Trading Co., who arrived in Rabwah to gather materials for a new publication about Islam as well as do business. It is worth noting that Rabwah later became the world headquarters of the Ahmadiyya movement, before they were moved to London.

57 Zafrullah Khan was an extremely popular Pakistani foreign minister and diplomat. As Pakistan's representative to the Security Council of the UN in 1948-1954 (he was Pakistan's Permanent Representative in 1961-1964 and President of the UN General Assembly in 1962-1964), he advocated independence for many occupied countries around the world, including Indonesia, and was a supporter of universal human rights (he served on the International Court of Justice in the Hague 1954-1961). Pakistan joined Afghanistan, Egypt, Iran, Iraq, Lebanon, Syria, and Turkey as the only Muslim countries that voted for the Universal Declaration of Human Rights, adopted by the UN General Assembly on December 10, 1948. 
was more fascinating to him than Muhammad Iqbal, the poet known as the 'spiritual father of Pakistan'. In the second letter addressed to 'Bung', Bahrum compares Zafrullah Khan and Muhammad Iqbal:

Bung, I think that Iqbal has a more objective attitude to Islam than even Zafrullah. Both of them are right in what they say about appraising and studying other cultures. But Zafrullah is 'dogmatic' about the truth of his Islamic conception of things, whereas Iqbal's attitude is one of 'independent-mindedness and respect', although this could be called a kind of dogma. Maybe it is clearer to put it this way: Zafrullah is no longer seeking for something; in the language of the arts, he has already 'arrived', whereas Iqbal still wants to keep searching. ${ }^{58}$

Transposed to an Indonesian context, in Bahrum's eyes, Zafrullah and Iqbal stand for Hamka and Takdir Alisjahbana in their manner of evaluating Islam and Islamic culture. ${ }^{59}$

The difference between the visions of Iqbal and Takdir and the outcomes of their ideals is also of interest. Both men urged Asians to 'inhale the spirit of the West' or to 'absorb the lessons of practical Islam' (Takdir) or to 'approach modern knowledge with an independent mind' (Iqbal). Both of these Asian thinkers arrived at these formulations through their searching readings of Western philosophy. ${ }^{60}$

It is important to underline the importance of Bahrum's observations here. In these years Muslim countries had just freed themselves from the grip of Western colonialism. As newly independent countries made their appearance, nationalizing movements grew apace. As a result, most Muslims in these countries felt antipathy to everything that derived from their former colonial masters. They

58 Bung, aku berpendapat bahwa Iqbal lebih objektif sikapnja terhadap Islam dari pada Zafrullah sendiri. Kedua-dua mereka benar dalam menjatakan supaja menilai dan menelaah kebudajaan2 lainnja: hanja Zafrullah 'mendogma' kepada benarnja tjita Islam, sedangkan Iqbal hanjalah, sikap yang 'merdeka dan terhormat' kalaupun ini bisa disebutkan dogma. Atau barangkali lebih terang lagi; Zafrullah tidak mentjari lagi; dalam istilah seni, dia sudah 'arrive', sedang Iqbal masih mau mentjari. (Bahrum Rangkuti 1951b:286.)

59 Sutan Takdir Alisjahbana was the best known figure in the cultural debates in Indonesia during the 1930s. He advocated the wholesale exploitation of Western ideas in order to modernize Indonesia. See Achdiat K. Mihardja 1954.

60 Menarik hati pula perbedaan visi dan hasil visi ini antara Iqbal dan Takdir. Kedua-dua mereka ini menjerukan kepada bangsa Timur supaja 'menghisap roh Barat' atau 'roh Islam jang nuchter' (Takdir) atau 'menghampiri ilmu pengetahuan modern dengan sikap jang merdeka' (Iqbal). Kedua ahli pikir 'Timur' ini sampai kepada utjapan diatas oleh telaah mereka jang dalam tentang falsafat Barat (Bahrum Rangkuti 1951b:287). 
sought to purge and cast aside everything that was 'colonial'. Excessive feelings of this sort stuck to the body and soul of the new nation.

It can be immediately understood from the quoted passages above how important Iqbal's position was in the realm of Islamic cultural thinking at this time. Against the tide of anti-colonial euphoria that conflated everything 'colonial' with everything 'Western', Iqbal pushed for the investigation of and immersion in Western thought in a clear-sighted and independent-minded way. He opposed moving away from and abandoning such an effort.

Bahrum supported Iqbal's position at the right moment in time, just as Muslims drunk on newly won freedom rejected everything they thought was colonial. Through the translations and studies of Iqbal's work that poured forth in journals like Zenith, Indonesia, Hikmah, Pandji Masjarakat, and Gema Islam during the 1950s, Iqbal attained popularity in Indonesia. He was frequently cited by leading Indonesian intellectuals of the period.

Bahrum's enthusiasm for introducing Iqbal to a wider audience grew even stronger in 1953 when, in collaboration with Arif Husain, he translated one of Iqbal's important works, Asrar-i Khudi (Personal secrets, the Indonesian title was Rahasia-rahasia pribadi). Moh. Natsir wrote an afterword and Bahrum provided a 71-page foreword that explained how he acquired a copy of the work and the importance of this 'oleh-oleh' (souvenir) from his trip to Pakistan:

I obtained a copy of the original text in Farsi when I was in Lahore in 1950, when I was studying with Prof. Abdul Qador MA, Professor of Arabic and Farsi at Djami'atul Mubashereen, Rabwah. I learned a great deal about Iqbal's poetry from him. ${ }^{61}$

Asrar-i Khudi was written in verse in the manner of Jalal ad-Din Rumi's thirteenth-century Persian-language Mathnawi and published in 1915. The poems contain Iqbal's teachings about the self and the struggle for existence. He also accuses the Sufis of living a life of excessive comfort and isolation. Asrar-i Khudi urges its readers to work hard and improve themselves. ${ }^{62}$

61 Saja sendiri mendapat teks aslinja, jakni bahasa Farsi, di Lahore dalam tahun 1950, waktu saja mendjadi murid dari Prof. Abdul Qadir M.A. Mahaguru bahasa Arab dan Farsi di Djami'atul Mubashereen, Rabwah. Daripadanja banjak saja peroleh pengertian tentang sjair2 Iqbal (Bahrum Rangkuti 1953:13).

62 The year 1915 indicates the belatedness of the introduction of Iqbal's work to Indonesia. Rabindranath Tagore, for example, winner of the Nobel Prize in literature for 1913, was Iqbal's contemporary, but his work had already begun appearing in Indonesia in the 1940 s in translations by Anas Ma'ruf and Amal Hamzah, among others. The founding of an independent Pakistan in 1947 served to bring Iqbal's isolation to an end. 
Iqbal was Pakistan's spiritual father who helped blaze the trail of the country's independence. He was a hero. Iqbal's poem 'Muslim brotherhood', for example, was made the official song of the Muktamar Alam Islami in Karachi in $1951 .{ }^{63}$ In the 1950s and early 1960s the Pakistani embassy in Jakarta often celebrated 'Iqbal Day' on 22 February. These events usually featured poetry-reading contests of Iqbal's work and performances from Pakistan. ${ }^{64}$

In reality Iqbal did not belong to Pakistan alone. For Muslim intellectuals and artists in Indonesia he was the prototype of the ideal cultural figure who integrated Western philosophy with mastery of the Quran, Hadith, and the entire intellectual and spiritual tradition of Islam. He embodied the energy and intellectual dynamism of Islam; he was the Kant, Nietzsche, Goethe, and Fichte of the Muslim world, all wrapped up into one. ${ }^{65}$ In this, Iqbal mirrored in himself the Islamic philosophers of the past: Ibnu 'Arabi, Ibnu Sina, and others. The attention Iqbal drew to his own work stimulated interest in Western thought, a necessarily circuitous path of intellectual inquiry. ${ }^{66}$

On the other hand, Iqbal was known in Muslim activist circles as someone with political views tending toward socialism. As someone who grew up just as colonialism reached the height of its power, he knew from personal experience what it felt like to be 'colonized'. He could feel sympathy for communism as an expression of the struggle against colonialism and imperialism. ${ }^{67}$ With the world divided in an ideological sense into left and right, there was a widespread impulse to search for other alternatives. The Islamic world, with its socialist tendencies at that time, participated in this quest. Indonesia, Egypt, and Pakistan were Muslim countries that were also, in one way or another, socialist. Iqbal's socialism was a Godfearing socialism. His famous saying was: 'Bolshevism plus God almost equals Islam'. Thus Iqbal was central to the search for a third way. It is hardly surprising that Iqbal was the most quoted and excerpted author in Indonesian Muslim publications during this

63 A translation of this poem by Hamka can be found in Hikmah, Lebaran issue (1 May 1957): 13 .

64 At the celebration in honour of Iqbal in 1954 at the Hotel des Indes, Natsir read his poem 'Sikwa-Jawabi Sikwa' in a translation by Hamka. This poem can be found in Pandji Masjarakat (see Muh. Iqbal 1959). For the celebration of Iqbal in 1958, the leader of Masjumi, Prawoto Mangkusasmito gave an address titled 'Iqbal's mission and ideals in the struggle for Islam in Indonesia', later published in Hikmah. See Prawoto Mangkusasmito 1958.

65 It was said that Iqbal was much influenced by these philosophers.

66 See, for example, Mumtaz Hasan (1960), 'Goethe and the East'. Mumtaz was inspired to write this piece because of Iqbal's 'spiritual-intellectual' link with Goethe.

67 One of the best known poems from Asrar-i Khudi is 'Lenin di depan Tuhan' (Lenin before God), a lyric poem that alternates between interest in, disregard for, praise, and mockery of Lenin's communism. 
period. ${ }^{68}$ It can be said that Iqbal was the connecting link between Islam in Indonesia and Islam in Pakistan. ${ }^{69}$ Most of the commentary on Iqbal was based on Bahrum Rangkuti's translation of and long introduction to Asrar-i Khudi. Throughout the 1950s and after, Bahrum was Iqbal's main interpreter in Indonesia. ${ }^{70}$

Bachrum subsequently became head of the Muslim pastoral service of the Indonesian navy with the rank of captain. He also fostered the development of the magazine Gema Islam and ended his career as Secretary-General of the Department of Religion under A. Mukti Ali (1971-1977). ${ }^{71}$ Apart from being well known as a writer and commentator on literature, he also wrote frequently on topics having to do with Pakistan. ${ }^{72}$ What he never forgot was the year he spent studying in Pakistan, which made a deep mark on Islam and culture in Indonesia. This was the trace of Muhammad Iqbal's presence in Indonesia.

68 See, for example, Kasim Mansoer (1956) in 'Muhammad Iqbal'; Rusdy Toana (1958) in 'Dr. Mohammad Iqbal'; N.M. Sutan Maricar (1960) in 'Iqbal; Penyair Internasional'; Abdullah Anwar Beg (1962) in 'Dr. Muhammad Iqbal di tengah Failasuf Islam dan Barat' (summary by Yusuf Abdullah Puar); and a comic strip about Iqbal by C. Israr that appeared in Gema Islam 4-68 (15 February 1965):33.

69 It is also important to take note of the speech by Iqbal collected in The reconstruction of religious thought in Islam which was published in two versions translated by Ali Audah, Goenawan Mohamad, and Taufik Ismail (Iqbal 1966a) and Osman Raliby (Iqbal 1966b). Iqbal's magnum opus, Javid Nama, did not appear in Indonesian until 1987. There is an indirect connection between this translation and Bahrum. In his introduction, the translator Mohamad Sadikin writes: 'I caught sight of him [Bahrum] at TIM in 1974 at an occasion in honour of Iqbal. The first work by Iqbal that I came to know was his Rahasia-rahasia pribadi, the translation of [...] Asrar-i Khudi. Later [...] I asked Bahrum when he was going to translate the Javid Namah?' Apparently Bahrum had wanted to translate this work for some time, but had been too busy with other things to do so. Not long after this conversation, Bahrum passed away. The Indonesian translation by Mohamad Sadikin (1987) is based on translations in French and English, rather than the original Persian, as Bahrum would have wanted. 70 Bahrum's journey to Pakistan is often interpreted as an indication of his adherence to Ahmadiyya. Several members of Ahmadiyya still remember him as a follower of that sect. According to Djohan Effendi, Bahrum belonged to Ahmadiyya for a period of time, then left the sect (interview with Djohan Effendi, January 2009). Djohan Effendi, who served in the Department of Religion and as a cabinet secretary in the Abdurrahman Wahid period, is a Muslim intellectual and admirer of Iqbal. He has translated three books about Iqbal (see Bilgrami 1979; Maitre 1981; Djohan Effendi 1986). Djohan was on good terms with Bahrum and stayed him during his first visit to Jakarta in the early 1970 s.

71 A. Mukti Ali was a member of the editorial board of Gema Islam and had been a student in the Department of Arabic Literature at the University of Karachi from 1951 to 1955. Like Hamka, Mukti wanted initially to study in Mecca, but Imron Rosyadi, Indonesian embassy consul in charge of the haj, advised him to go to Egypt because the influence of the Wahabis was too great to allow for the disinterested pursuit of knowledge (see Abdurrahman 1993). In the end Mukti chose Pakistan. Apart from the fact that friends of Imron Rosyadi were there, Mukti was drawn to the ideas of Muhammad Iqbal (information obtained from Martin van Bruinessen, 27 February 2009). 72 Apart from his visits to Pakistan, Bahrum also obtained copies of the latest books and publications about Pakistan from his friend Arif Husain, who was on the staff of the Pakistani Embassy in Jakarta and an expert in Persian. 


\section{CONCLUSION}

In 1950, Asrul Sani and his friends proclaimed the Gelanggang Testimonial of Beliefs (Surat Kepercayaan Gelanggang), a succinct document brimming with vitality. Its contents set forth the certitude of their belief in themselves as members of 'the legitimate heirs to world culture'. It was a resonant claim to open Indonesian culture to the world. 'The culture of Indonesia is established by the coming together of clamorous voices spurred by voices hurled from every corner of the world [...]', in the words of the Testimonial. ${ }^{73}$

To locate the cultural journeys, quests, and struggles in Egypt and Pakistan of the three Muslim intellectuals we have been examining on a continuum with the ideas expressed by the Gelanggang Testimonial is not to misrepresent them. It can be said in fact that the acts and ideas of these three men represent a concrete response to the directives and challenges of this text. Travelling to two Muslim countries can be seen as an enactment of the decision to search for and seize hold of those 'voices hurled from every corner of the world'.

In an editorial titled 'Kebudajaan Arab atau kebudajaan Islam' (Arab culture or Muslim culture), Hamka (1960) responded to the charge that the magazine Pandji Masjarakat was promoting Arab culture. While conceding that this was true, Hamka turned the argument on its head. If every element of culture from around the world, be it from India, Europe, Hindu, Buddhist, Chinese, or even communist for that matter, could be said to be contributing to the formation of the 'national culture' of Indonesia, why not Arab culture, why not Islam? Hamka's question seems to echo once again the words of the Gelanggang Testimonial quoted above.

But what kind of 'Islam' would be the most appropriate and helpful in this process? Hamka, Usmar, and Bahrum were all convinced that it would be the modern and progressive Islam that placed value and importance on scientific knowledge. It was this culture of Islam that they sought to introduce through their essays, films, and literary translations. It was in Egypt and Pakistan, it is important to stress, that they discovered the kind of modern, progressive, and enlightened Islam that could best contribute to the development of an independent and modern Indonesia.

\section{Translated from Indonesian by Tony Day}

73 'Kebudayaan Indonesia ditetapkan oleh kesatuan berbagai-bagai rangsang suara yang disebabkan suara-suara yang dilontarkan dari segala sudut dunia [...]'. See the reprint of the entire text in Asrul Sani 1997:3-4. An English translation of the text can be found in Teeuw 1986:127. 
REFERENCES

Abaza, Mona

$1993 \quad$ Changing images of three generations of Azharites in Indonesia. Singapore: Institute of Southeast Asian Studies. [Occasional paper 88.]

1996 'A profile of an Indonesian Azhari living in Cairo', Archipel 52:31-44.

Abdurrahman et al. (eds)

1993 Agama dan masyarakat; 70 tahun Mukti Ali. Yogyakarta: IAIN Sunan Kalijaga Press.

Aboebakar Atjeh (ed.)

1957 Sedjarah hidup K.H.A. Wahid Hasjim dan karangan tersiar. Djakarta: Panitya Buku Peringatan Almarhum K.H.A. Wahid Hasjim.

Abdullah Anwar Beg

1962 'Dr. Muhammad Iqbal di tengah failasuf Islam dan

Barat', Gema Islam 1-3 (15 February):8-10. [Translation by Yusuf Abdullah Puar.]

Abu Ubaidah (pseudonym of Moh. Dimyati)

1952 'Dancing bar dan tempat djudi', Hikmah 5-41 (11 October):21.

Achdiat K. Mihardja (ed.)

1954 Polemik kebudajaan; Pokok pikiran. Tj. k-3. Djakarta: Perpustakaan Perguruan, Kementerian Pendidikan Pengadjaran dan Kebudajaan (PP dan K). [Balai Pustaka 1661.]

[First edition 1948.]

Adnan Syamni

1954

'Dari tjatatan perdjalanan ke Pakistan', Hikmah 7-23 (5 June):11-2, 22.

Ahmad Shalaby

1957

Masjarakat Islam. Djakarta: Ahmad Nabhan.

1959

'Mentjapai masjarakat Islam dalam ikatan ke-Islaman', Pan-

Ahmed Ali

dji Masjarakat 1-1 (15 June):14-5, 30.

1951

'Kebudajaan Pakistan', in: R. Symonds (ed.), Pembinaan Pakistan, pp. 225-56. Djakarta: Balai Pustaka. [Translation by Anas Ma'ruf.]

Ajip Rosidi (ed.)

1997

Asrul Sani 70 tahun. Jakarta: Pustaka Jaya. 
Ali Audah

1966 'Muhammad Iqbal; Sebuah pengantar', in: Muhammad Iqbal (ed.), Membangun kembali pikiran agama dalam Islam, pp. ix-xxxv. Djakarta: Tintamas.

Ali Fahmi Al-Amrousi

1959

'Revolusionerisme Nabi Muhammad dalam membina ummat baru', Pandji Masjarakat 1-10 (1 November):9-11.

Amal Hamzah

1952 Pakistan; Sebuah negara Islam muda. Djakarta: Djambatan.

Amura (Abdul Muin Rafi'ah Ali)

1962 'Pengaruh Film bagi Angkatan Muda', Gema Islam 1-17 (1 October):8.

1977 'Dengan Buya Hamka dalam berbagai peristiwa', in: Panitia

Kenang-kenangan 70 tahun Hamka (ed.), Kenang-kenangan 70 tahun Buya Hamka, pp. 198-206. Jakarta: Yayasan Nurul Islam.

Arief Mudatsir Mandan (ed.)

2008 Napak tilas pengabdian Idham Chalid; Tanggung jawab politik NU dalam sejarah. Jakarta: Pustaka Indonesia Satu.

Asrul Sani

1983 'Sebuah Apresiasi', in: Usmar Ismail, Usmar Ismail mengupas film, pp. 9-12. Jakarta: Sinar Harapan.

1997 Surat-surat kepercayaan. Jakarta: Pustaka Jaya.

Azyumardi Azra

1999

'The transmission of al-Manar's reforms to the Malay-Indonesian world; The cases of al-Imam and al-Munir', Studia Islamika 6-3:77-99.

Bahrum Rangkuti

$1951 \mathrm{a} \quad$ 'Setahun di negeri bulan bintang I', Zenith 1-4:225-339.

1951 b 'Setahun di negeri bulan bintang II', Zenith 1-5:283-97.

1953 'Pengantar kepada Cita Iqbal', in: Muhammad Iqbal, Asrar-i

Khudi; Rahasia2 pribadi, pp.13-71. Djakarta: Pustaka Islam.

Bilgrami, H.H.

1979

Iqbal; Sekilas tentang hidup dan pemikirannya. Jakarta: Bulan Bintang. [Translation by Djohan Effendi.]

Deliar Noer 1983

'Yamin dan Hamka; Dua jalan menuju identitas nasional', in: Anthony Reid and David Marr (eds), Dari Raja Ali Haji hingga Hamka, pp. 37-52. Jakarta: Grafiti. [Translation by Th. Sumartana.]

Partai Islam di pentas nasional. Jakarta: Grafiti. 
Djohan Effendi dan Abdul Hadi W.M. (eds.)

1986

Iqbal; Pemikiran sosial Iqbal dan sajak-sajaknya. Jakarta: Pantja Simpati.

Emzita

1977

'Seorang Ulama dan Pujangga Islam Indonesia', in: Panitia Kenang-kenangan 70 tahun Hamka (ed.), Kenang-kenangan 70 tahun Buya Hamka, pp. 89-103. Jakarta: Yayasan Nurul Islam.

Fuad Fachruddin

1991

'Sejarah siapa yang menentukan, siapa Sjaichu', in: Saifullah Ma'shum (ed.), Kembali ke pesantren; 70 tahun K.H. Ahmad Sjaichu, pp. 153-7. Jakarta: Yayasan Alhamidiyah.

Gema Islam berusia

1963 'Gema Islam berusia satu tahun', Gema Islam 2-24 (15 April):7.

Gema K.I.A.A.

1965 'Gema K.I.A.A', Gema Islam 4-68 (15 February):26.

Hamka (Haji Abdul Malik Karim Amrullah)

1951 Kenang-kenangan hidup II. Djakarta: Gapura.

1952 Di lembah sungai Nil. Djakarta: Gapura.

1958 Ajahku; Riwajat hidup Dr. Abd. Karim Amrullah dan perdjuangan kaum agama di Sumatera. Tjet. ke-2. Djakarta: Widjaja. [First edition 1950.]

1960 'Kebudajaan Arab atau kebudajaan Islam', Pandji Masjarakat 2-16 (1 February):2.

1984 'Haji Agus Salim sebagai sastrawan dan ulama', in: Panitia 100 Tahun (ed.) 100 Tahun H. Agus Salim, pp. 252-65. Jakarta: Sinar Harapan.

Indonesia O'Galelano

1964 'Film dokumenter hadji 1963', Gema Islam 3-47/48 (15 April):28-9.

Iqbal, Muh.

1953 Asrar-i Khudi; rahasia2 pribadi. Djakarta; Pustaka Islam [translation by Bahrum Rangkuti].

1959 'Sjikwa - Jawabi Sjikwa', Pandji Masjarakat 1-3 (15 July):2-3. [Translation by Hamka.]

1966a Membangun kembali pikiran agama dalam Islam. Djakarta: Tintamas. [Translation by Ali Audah, Taufik Ismail, Goenawan Mohamad.]

1966b Pembangunan kembali alam pikiran Islam. Djakarta: Bulan Bintang. [Translation by Osman Raliby.] 
Javid Namah: kitab keabadian [translation by Mohamad Sadikin]. Jakarta: Pustaka Panjimas.

Iskandar Zulkarnain

2005

Gerakan Ahmadiyah di Indonesia. Yogyakarta: LKIS.

Ismail Banda

1947

Pengakoean Mesir dan politik Arab League. Jogjakarta: Himpoenan Mahasiswa Islam.

Jakob Oetama

1963 'Bahrum Rangkuti; Sastrawan pengagum Iqbal', Intisari 2:7-11. Jedamski, Doris 2002

'Popular literature and postcolonial subjectivities; Robinson Crusoe, the Count of Monte Cristo and Sherlock Holmes in colonial Indonesia', in: Keith Foulcher and Tony Day (eds), Clearing a space; Postcolonial readings of modern Indonesian literature, pp. 19-47. Leiden: KITLV Press. [Verhandelingen 202.]

Joesoef Ahmad

196 'Satu tahun "Gema Islam”; J.P.I.P harus punja pertjetakan sendiri', Gema Islam 2-24 (15 April):8.

Junus Amir Hamzah

1963 Tenggelamnja kapal Van Der Wijck dalam polemik. Djakarta: Mega Book Store.

Kasim Mansoer

1956 'Muhammad Iqbal', Hikmah 9-14 (14 April):20-1.

Kimche, David

1973 The Afro-Asian movement; Ideology and foreign policy of the third world. Jerusalem: Israel University Press.

Laffan, Michael

2004 'An Indonesian community in Cairo; Continuity and change in a cosmopolitan Islamic milieu', Indonesia (Cornell University) 77:1-26.

Maitre, Luce-Claude

Pengantar ke pemikiran Iqbal. Jakarta: Pustaka Kencana. [Translation by Djohan Effendi.]

Misbach Yusa Biran,

2008 Kenang-kenangan orang bandel. Jakarta: Komunitas Bambu.

Mohamad Hatta

1960 'Demokrasi kita', Pandji Masjarakat 2-22 (1 May):3-8.

Mohamad Sadikin

1987 'Prakata', in: Mohamad Iqbal, Javid Namah; Kitab keabadian, pp v-viii. Jakarta: Pustaka Panjimas. 
Mohammad Mahmoud Ridwan

1960 'Alam Islamy di zaman depan', Pandjimas 2-20 (28 March):10-12.

1962 'Film keagamaan Islam', Gema Islam 1-6 (15 April):20-1.

Mumtaz Hasan

1960 'Gothe dan dunia timur', Pandji Masjarakat 2-21 (15 April):14-15.

Nunus Supardi 2007

Kongres kebudayaan (1918-2003). Yogyakarta: Ombak.

Osman Raliby 1966

'Sedikit tentang Iqbal', in: Muhammad Iqbal, Pembangunan kembali alam pikiran Islam, pp. xiii-xxviii. Djakarta: Bulan Bintang.

Ohorella, G.A. 1985

Prof. dr. Abu Hanifah Dt. M.E.; Karya dan pengabdiannya. Jakarta: Proyek Inventarisasi dan Dokumentasi Sejarah Nasional, Direktorat Sejarah dan Nilai Tradisional, Departemen Pendidikan dan Kebudayaan.

Prawoto Mangkusasmito

1958 'Missi Iqbal dan tjita2 perdjuangan Islam di Indonesia', Hikmah 11-13 (10 May):5-6.

Ramadhan K.H.

1982 Gelombang hidupku; Dewi Dja dari Dardanella. Jakarta: Sinar Harapan.

Ramadhan K.H. and Nina Pane

2006 Djamaluddin Malik; Melekat di hati banyak orang. Jakarta: Kata Hasta Pustaka.

Rasyad, Aminuddin

1977 'Kartini perguruan tinggi Islam', Prisma 8:101-12.

Rhoma Dwi Aria Yuliantri and Muhidin M Dahlan (eds)

2008

Lekra tak membakar buku; Suara senyap lembar kebudayaan Harian Rakyat 1950-1965. Yogyakarta: Merakesumba.

Roff, William

1970 'Indonesian and Malay students in Cairo in the 1920's', Indonesia (Cornell University) 9:73-87.

Rosihan Anwar

1977

'Hamka dan "Gema Islam" dan kumandang dakwah', in: Panitia Kenang-kenangan 70 tahun Hamka (ed.), Kenangkenangan 70 tahun Buya Hamka, pp. 155-9. Jakarta: Yayasan Nurul Islam. 
1983

Menulis dalam air; Di sini sekarang, esok hilang, sebuah otobiografi. Jakarta: Sinar Harapan.

Rusydi

1983

Pribadi dan martabat buya prof. dr. Hamka. Jakarta: Pustaka Panjimas.

Rusdy Toana

1958 'Dr. Mohammad Iqbal', Hikmah 11-13 (10 May):18-9.

Saifuddin Zuhri

1986 Berangkat dari pesantren. Jakarta: Gunung Agung.

Saifullah Ma'shum (ed.)

1994 Menapak jejak mengenal watak. Jakarta: Yayasan Saifuddin Zuhri.

Salim Said

1991 Dunia film Indonesia. Jakarta: Pustakakarya Grafikatama.

Sambutan M.K.N/KASAD

1962 'Sambutan M.K.N/KASAD Djenderal A.H. Nasution', Gema Islam 1-1 (15 January):4.

Sebab 'Pandji Masjarakat'

1959 'Sebab "Pandji Masjarakat" didirikan', Pandji Masjarakat 1-1 (15 June):2.

Semangat Baru

1960

'Semangat Baru di AL AZHAR University', Pandji Masjarakat 2/4-17:17.

Sidi Gazalba

1962

Mesjid; pusat ibadat dan kebudajaan Islam. Djakarta: Pustaka Antara.

Soebagijo I.N.

1981 Jagat wartawan Indonesia. Jakarta: Gunung Agung.

1985

'Dari Saridi ke Rasjidi', in: 70 tahun prof. dr. H. M. Rasjidi,

Sutan Maricar pp. 3-92. Jakarta: Pelita.

1960

'Iqbal: Penjair Internasional', Pandji Masjarakat 2-22 (1 May):26-9.

Taufik Ismail and D.S. Moeljanto (eds)

1995

Prahara budaya; Kilas-balik ofensif LEKRA/PKI dkk; Kumpulan dokumen pergolakan sejarah. Jakarta: Mizan dan HU Republika.

Teeuw, A.

1952

Pokok dan tokoh dalam kesusasteraan Indonesia baru II. Djakarta: P.T. Pembangunan. 
1986 Modern Indonesian literature, vol. I . Third edition. Dordrecht: Foris Publications.

Usmar Ismail

1964 'Kerdjasama umat Islam di lapangan kebudajaan', Gema Islam 3-49 (1 May):17.

1983 Usmar Ismail mengupas film. Jakarta: Sinar Harapan.

Zein Hassan

1980

Diplomasi revolusi Indonesia di luar negeri. Jakarta: Bulan Bintang. 